Article

\title{
Early Cretaceous Plume-Ridge Interaction Recorded in the Band-e-Zeyarat Ophiolite (North Makran, Iran): New Constraints from Petrological, Mineral Chemistry, and Geochronological Data
}

\author{
Edoardo Barbero ${ }^{1}\left({ }^{\circ}\right.$, Morteza Delavari $^{2}\left(\mathbb{D}\right.$, Ashgar Dolati ${ }^{2}\left({ }^{\circ}\right.$, Leila Vahedi ${ }^{2}$, \\ Antonio Langone ${ }^{3(\mathbb{D}}$, Michele Marroni ${ }^{4,5, *(\mathbb{D})}$, Luca Pandolfi ${ }^{4,5}$, Federica Zaccarini ${ }^{6}$ \\ and Emilio Saccani ${ }^{1}$ \\ 1 Dipartimento di Fisica e Scienze della Terra, Università di Ferrara, 44123 Ferrara, Italy; \\ brbdrd@unife.it (E.B.); sac@unife.it (E.S.) \\ 2 Faculty of Earth Sciences, Kharazmi University, Tehran 15719-19911, Iran; delavarimza@gmail.com (M.D.); \\ dolati@gmx.com (A.D.); leila.vahedi@ymail.com (L.V.) \\ 3 Istituto di Geoscienze e Georisorse, Consiglio Nazionale delle Ricerche (IGG-CNR), 27100 Pavia, Italy; \\ langone@crystal.unipv.it \\ 4 Dipartimento di Scienze della Terra, Università di Pisa, 56126 Pisa, Italy; luca.pandolfi@unipi.it \\ 5 Istituto di Geoscienze e Georisorse, Consiglio Nazionale delle Ricerche (CNR), 56124 Pisa, Italy \\ 6 Department of Applied Geological Sciences and Geophysics, University of Leoben, 8700 Leoben, Austria; \\ federica.zaccarini@unileoben.ac.at \\ * Correspondence: michele.marroni@unipi.it
}

Received: 16 November 2020; Accepted: 3 December 2020; Published: 7 December 2020

\begin{abstract}
The North Makran domain (southeast Iran) is part of the Makran accretionary wedge and consists of an imbricate stack of continental and Neo-Tethyan oceanic tectonic units. Among these, the Band-e-Zeyarat ophiolite consists of (from bottom to top): ultramafic cumulates, layered gabbros, isotropic gabbros, a sheeted dyke complex, and a volcanic sequence. Sheeted dykes and volcanic rocks are mainly represented by basalts and minor andesites and rhyolites showing either normal-type $(\mathrm{N})$ or enriched-type (E) mid-ocean ridge basalt affinities (MORB). These conclusions are also supported by mineral chemistry data. In addition, E-MORBs can be subdivided in distinct subtypes based on slightly different but significant light rare earth elements, $\mathrm{Th}, \mathrm{Nb}, \mathrm{TiO}_{2}$, and Ta contents. These chemical differences point out for different partial melting conditions of their mantle sources, in terms of source composition, partial melting degrees, and melting depths. U-Pb geochronological data on zircons from intrusive rocks gave ages ranging from 122 to $129 \mathrm{Ma}$. We suggest that the Band-e-Zeyarat ophiolite represents an Early Cretaceous chemical composite oceanic crust formed in a mid-ocean ridge setting by partial melting of a depleted suboceanic mantle variably metasomatized by plume-type components. This ophiolite records, therefore, an Early Cretaceous plume-ridge interaction in the Makran Neo-Tethys.
\end{abstract}

Keywords: ophiolite; petrology; U-Pb zircon geochronology; plume-ridge interaction; Makran accretionary prism; Cretaceous; Iran

\section{Introduction}

Ophiolites may originate in a variety of oceanic settings such as mid-ocean ridges, supra-subduction zones, marginal basins, and ocean islands. For each setting of origin, ophiolites show distinctive features in terms of lithological features and geochemical fingerprinting [1-9]. Thus, ophiolites can be used to identify their geodynamic setting of formation and, consequently, they can provide fundamental 
information for the reconstruction of the tectono-magmatic events that occurred during the life of an oceanic basin. To this purpose, the geochemistry of magmatic rocks forming an ophiolitic sequence is particularly useful for identifying the nature of mantle sources, thus providing valuable insights for discriminating the geodynamic setting where the ophiolites originated $[9,10]$. These data, coupled with the geochronological data, represent an effective tool for the reconstruction of the geodynamic history of oceanic basins.

In the North Makran (southeast Iran), several ophiolitic units crop out at the rear of the accretionary wedge developed within the convergent margin resulting from the subduction of the Neo-Tethyan oceanic lithosphere beneath the Lut and Afghan continental blocks (Figure 1a) [11-14]. All these ophiolitic units are interpreted as the remnants of the Early Cretaceous North Makran Ocean located south of Lut and Afghan continental blocks [15-19]. This oceanic basin was interpreted as either a marginal basin $[15,16]$ or a back-arc basin related to the Neo-Tethys northward subduction [17-19]. This oceanic basin played an important role during the Late Cretaceous-Eocene convergent tectonics, when the North Makran acquired most of its present-day tectonic setting [15,16,20-23]. In the North Makran, one of the best-preserved ophiolitic sequences is represented by the Band-e-Zeyarat Unit [24]. This unit includes (from bottom to top) ultramafic cumulates, layered gabbros, isotropic gabbros, a sheeted dyke complex, and a volcanic sequence. Despite its importance for the reconstruction of the geodynamics of the Makran area, the only available geochemical data for the Band-e-Zeyarat Unit are those given by Ghazi et al. [24], whereas sparse age data obtained from amphiboles and whole rocks were presented by Ghazi et al. [24] and Kananian et al. [25]. Ghazi et al. [24] have shown that the Cretaceous Band-e-Zeyarat basalts display enriched mid-ocean ridge (E-MORB) chemical affinity. Likewise, Saccani et al. [22] and Esmaeili et al. [26] have documented a widespread occurrence of Cretaceous enriched-type basalts, such as E-MORB and alkaline basalts, in several units of the North Makran. These authors have suggested that the enriched nature of these basalts can be related to mantle sources enriched by plume-type components. On the other hand, mantle plume activities were commonly active at a worldwide scale during Cretaceous times [27-31]. Therefore, the possibility that the Band-e-Zeyarat ophiolites record a mantle plume activity and plume-ridge interaction processes in the Makran sector of the Neo-Tethys during the Cretaceous times is worth investigating. For this reason, we present new detailed stratigraphic data, as well as mineral chemistry and whole rock geochemical data on the Band-e-Zeyarat ophiolite sequence. We also present new U-Pb geochronological data on zircons separated from plagiogranites found in the isotropic gabbro series. We anticipate that these new data provide robust constraints for the reconstruction of the tectono-magmatic setting of formation of the Cretaceous Neo-Tethys to the south of the Lut continental block. 

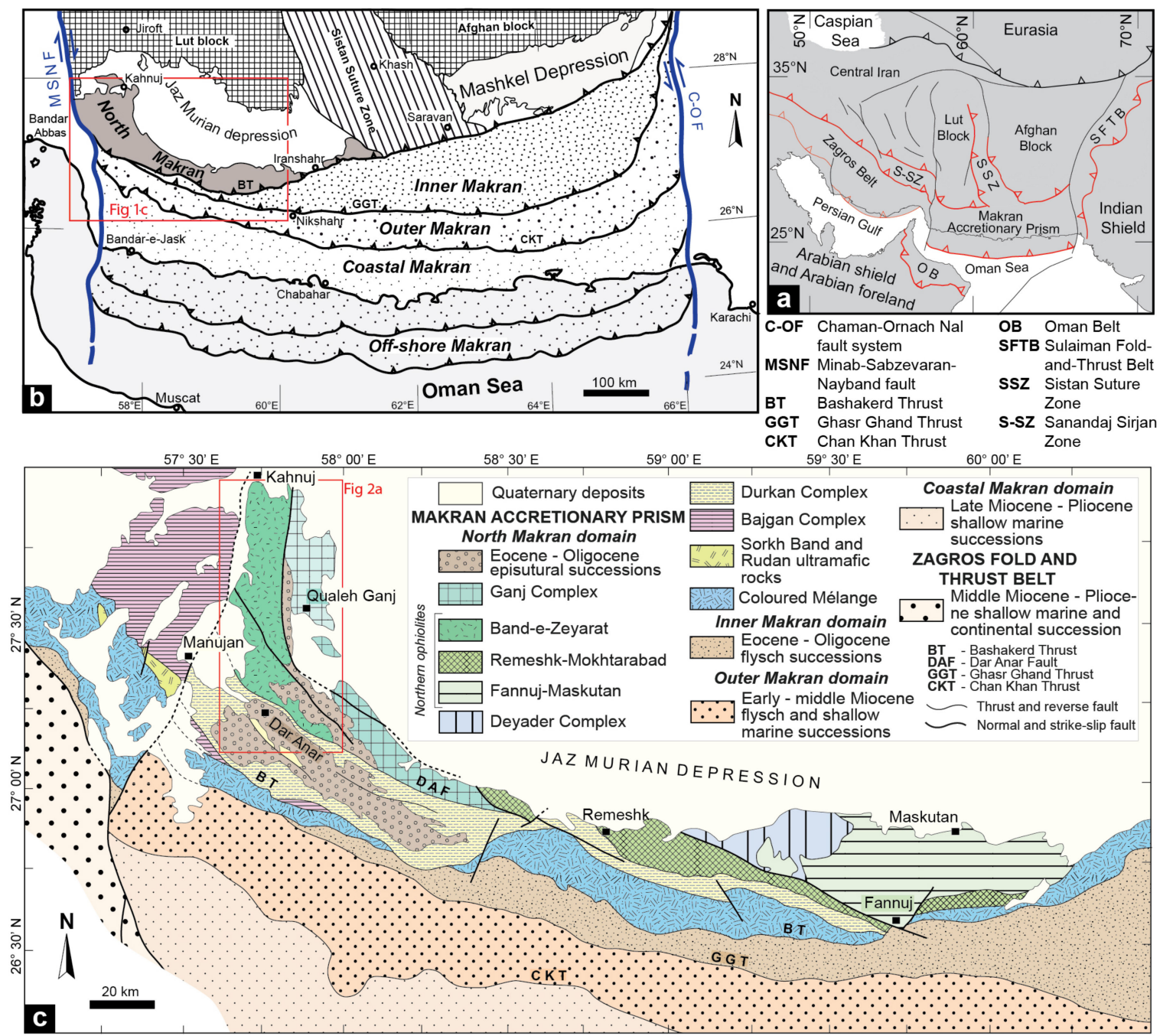

Figure 1. Tectonic sketch map of the Middle East area (a) showing the main tectonic plates and convergent zones (modified from Bagheri and Stampfli [32]; Zanchetta et al. [33]; Mohammadi et al. [34]; Pirnia et al. [35]; Barbero et al. [23]). (b) Simplified structural map of the Makran Accretionary Wedge (modified from Burg et al. [13]), (c) simplified geological-structural map of the North Makran Domain showing the different tectonic units (modified from Eftekhar-Nezhad et al. [36]; Samimi Namin [37,38]; Hunziker et al. [15]; Burg [16]; Barbero et al. [23]).

\section{Geological Setting}

The Makran Accretionary Prism (Figure 1a,b) extends between the Minab-Sabzevaran-Nayband dextral fault system and the Chaman-Ornach-Nal sinistral fault system $[12,14,39]$, separating the still active Makran subduction zone from the Zagros fold-and-thrust belt and the Himalayan continent-continent collision zones, respectively (Figure 1a). The Makran Accretionary Prism formed in response to the Cretaceous-Present day northward subduction of the Neo-Tethys oceanic lithosphere beneath the Lut and Afghan continental blocks, which are parts of the southern Eurasia margin $[16,18,22,40,41]$. The subduction is related to the convergence between the Arabia and Eurasia plates $[40,42,43]$, which is still active beneath the Makran, as outlined by the geophysical and earthquake focal mechanisms data [12,44,45]. In the Makran Accretionary Prism, four tectono-stratigraphic domains have been distinguished $[13,46]$ including from the structural top to the bottom (i.e., from north to south): (1) the North Makran, (2) the Inner Makran, (3) the Outer Makran, and (4) the Coastal Makran (Figure 1b). The North Makran includes several tectonic units derived from the deformation of both oceanic (largely predominant) and continental (largely subordinate) domains. 
These units record the pre-Eocene geodynamic history of the Makran Accretionary Prism [20,47,48]. In contrast, the Inner, Outer, and Coastal Makran document the post-Eocene filling of trench and thrust-top basins, which have been progressively deformed in the frontal part of the prism since the Miocene [13,16,46,49-51]. The tectonic units of the North Makran tectono-stratigraphic domain are bounded by high- to low-angle shear zones $[22,23,36,38,47,51]$ and are, from north to south and from the uppermost to the lowermost unit (Figure 1c): (1) the Ganj Complex, (2) the Northern Ophiolites (Inner Makran Spreading Zone of McCall and Kidd [17]), (3) the Bajgan and Durkan Complexes, (4) the Deyader Metamorphic Complex, (5) the Sorkhband-Rudan ophiolitic slices, and (6) the Colored Mélange (Imbricate Zone of Burg et al. [13]).

The Ganj Complex consists of a basal swarm of crosscutting and sub-parallel dykes, which passes upward to a volcano-sedimentary sequence, followed, in turn, by a Turonian-Coniacian turbiditic sequence (Figure 1c). The early geological studies and mapping of the Makran area made in the 1980s [47] have included this Complex within the North Makran Ophiolites. However, Barbero et al. [23], based on biostratigraphic, geochemical, and petrological data, have re-interpreted the Ganj Complex as a volcanic arc, forming close to the southern margin of the Lut Block during the Late Cretaceous.

The North Makran Ophiolites include several distinct units (Figure 1c), which are: The Band-e-Zeyarat [24,25], Remeshk-Mokhtarabad [16,17,20,52], and Fannuj-Maskutan units [21,53]. These ophiolites show Early to Late Cretaceous ages and magmatic rocks displaying different geochemical features. In detail, the Early Cretaceous ophiolites have enriched mid-ocean ridge basalt (E-MORB) geochemical affinity, whereas the Late Cretaceous units display supra-subduction zone geochemical affinity $[16,18,19,24,53]$. The Band-e-Zeyarat ophiolite consists of an incomplete ophiolitic sequence characterized by cumulate and isotropic intrusive rocks, a sheeted dykes complex, and pillow basalts interbedded with and capped by pelagic sedimentary rocks [20,24]. ${ }^{40} \mathrm{Ar}-{ }^{39} \mathrm{Ar}$ and ${ }^{40} \mathrm{~K}-{ }^{40} \mathrm{Ar}$ dating performed on hornblende from the isotropic gabbros yielded crystallization ages of 136-156 Ma (i.e., Early Cretaceous) [24,25]. In addition, whole-rock and mineral separates (i.e., amphibole and plagioclase) ${ }^{40} \mathrm{~K}-{ }^{40} \mathrm{Ar}$ dating yielded ages of $128-112 \mathrm{Ma}$ and $128-88 \mathrm{Ma}$ for diorites and plagiogranites, respectively [25]. In contrast, the Fannuj-Maskutan and Remeshk-Mokhtarabad ophiolites show a complete ophiolitic sequence from mantle peridotites to pillow-lava basalts [16,19,52,53]. Pillow basalts are capped by an Early Cretaceous pelagic sedimentary cover [46]. All these ophiolites are considered as the remnants of an Early Cretaceous oceanic basin, i.e., the North Makran Ocean, which was interpreted as either a marginal basin opened during the Late Jurassic-Early Cretaceous at the southern margin of the Lut Block $[15,16]$ or a back-arc basin and/or supra-subduction zone basin related to the Neo-Tethys northward subduction [17-19]. Regardless of these different interpretations, the opening of the North Makran Ocean is thought to have led to the drift of the so-called Bajgan-Durkan microcontinent from the Lut Block [15-20].

The Bajgan and Durkan Complexes represent $\sim 250 \mathrm{~km}$ long and $\sim 40 \mathrm{~km}$ wide tectonic elements (Figure 1c). The Bajgan is a metamorphic complex that includes schists, paragneisses, amphibolites, and marbles, as well as basic and acidic meta-intrusive rocks and rare glaucophane-bearing schists $[20,47,54,55]$. In contrast, the Durkan Complex includes Lower Cretaceous-Paleocene successions, rare tectonic slices of Carboniferous, Permian, and Jurassic shelf carbonate rocks, and subordinate marbles and schists $[15,20,47]$. In addition, in the eastern sector of the Durkan Complex, different types of granitoids intruding into Permian and Jurassic shelf limestones have been described and were interpreted as originated in a continental margin setting during extensional tectonic phases [15]. The Bajgan and Durkan Complexes have been considered as derived from the deformation of a microcontinental block, known as the Bajgan-Durkan microcontinent, which is thought to represent the southeastward continuation of the Precambrian-Late Palaeozoic Sanandaj-Sirjan Zone [16,17,56].

The Deyader Metamorphic Complex is exclusively cropped out in the eastern sector of the North Makran domain (Figure 1c). It is made up by meta-limestones, metavolcanics, and meta-gabbros affected by Late Cretaceous high pressure-low temperature (HP-LT) metamorphism [15,47,57,58]. 
The ophiolitic Sorkhband and Rudan tectonic slices crop out in the western North Makran between the Colored Mélange and the Bajgan Complex (Figure 1c). They are also known as "the southern ophiolites" and consist of a tectonic slice of supra-subduction zone-type (SSZ) peridotites and a tectonic slice of mid-ocean ridge-type mafic rocks, both inferred as Mesozoic in age [20,51].

The Colored Mélange is characterized by an assemblage of metric- to decametric-thick slices that consist of volcanic rocks, cherts, limestones, serpentinites, gabbros, shales, as well as various types of metamorphic rocks $[20,22,26,54,59]$. Volcanic rocks show a wide range of geochemical affinity and age, including undated normal-type mid-ocean ridge basalts (N-MORB), alkaline basalts together with Turonian-Campanian oceanic plateau basalts, Hauterivian-Campanian island arc tholeiites, and Coniacian-Santonian calc-alkaline basalts [22,26]. The Colored Mélange is thought to have formed during the Late Cretaceous-Paleocene in response of the subduction of the Neo-Tethys oceanic lithosphere and includes remnants of both the subducting plate and the forearc-arc [22,47,54].

\section{Methods}

\subsection{Field Investigation and Petrography}

The field investigation was focused on the lithostratigraphic features of the Band-e-Zeyarat ophiolite. Particular attention has been focused on sampling plagiogranitic rocks suitable for zircon $\mathrm{U}-\mathrm{Pb}$ geochronology. Unfortunately, the study area is affected by abundant acidic dykes associated with Tertiary calc-alkaline magmatism [47], which are sometimes hard to be distinguished in the field from the plagiogranite dykes of the ophiolitic sequence. Therefore, a detailed field investigation proved necessary for unequivocally distinguishing ophiolitic plagiogranites from the Tertiary acidic dykes. Plagiogranites where taken from the transition between the intrusive and the sheeted dyke complexes in two distinct areas, namely the Chah Mirak and Bandkouh areas (Figure 2a), which were investigated in detail. The mineral composition and textures of the studied rocks were investigated in thin sections by a polarized light microscope.

\subsection{Whole-Rock Chemical Analysis}

Whole rock major and some trace elements were analyzed by X-ray fluorescence (XRF) on pressed-powder pellets using an ARL Advant-XP automated X-ray spectrometer (Thermo Fisher Scientific, Waltham, MA, USA). The matrix correction method proposed by Lachance and Trail [60] was applied. Volatile elements' content was determined as loss on ignition (LOI) at $1000{ }^{\circ} \mathrm{C}$. In addition, other trace elements, such as $\mathrm{Rb}, \mathrm{Sr}, \mathrm{Y}, \mathrm{Zr}, \mathrm{Nb}, \mathrm{Hf}, \mathrm{Ta}, \mathrm{Th}, \mathrm{U}$, and the rare earth elements (REE), were determined by inductively coupled plasma-mass spectrometry (ICP-MS) using a Thermo Series X-I instrument (Thermo Fisher Scientific, Waltham, MA, USA). Accuracy of the data and detection limits were evaluated using results for international standard rocks [61], run as unknown. Results for the different elements analyzed with different methods are given in Supplementary Table S1. All whole rock analyses were performed at the Department of Physics and Earth Sciences, Ferrara University. Representative analyses are shown in Supplementary Tables S2 and S3.

\subsection{Mineral Chemistry Analysis}

Silicates were analyzed by electron microprobe using a Superprobe Jeol JXA 8200 (JEOL, Tokyo, Japan) at the Eugen F. Stumpfl Laboratory at the University of Leoben, Austria, using both energy and wavelength dispersive systems (EDS and WDS, respectively). During the quantitative analyses of silicates, the electron microprobe was operated in the WDS mode, with an accelerating voltage of $15 \mathrm{kV}$ and beam current of $10 \mathrm{nA}$. The diameter of the beam was about $1 \mu \mathrm{m}$. Counting times were $20 \mathrm{~s}$ on the peak and $10 \mathrm{~s}$ on the left and right backgrounds. Standards (element, emission line) were: adularia ( $\mathrm{Al}$ and $\mathrm{Si}, \mathrm{K} \alpha)$, rutile $(\mathrm{Ti}, \mathrm{K} \alpha)$, chromite $(\mathrm{Cr}, \mathrm{K} \alpha)$, almandine $(\mathrm{Fe}, \mathrm{K} \alpha)$, rhodonite $(\mathrm{Mn}, \mathrm{K} \alpha)$, olivine $(\mathrm{Mg}, \mathrm{K} \alpha)$, wollastonite $(\mathrm{Ca}, \mathrm{K} \alpha)$, albite $(\mathrm{Na}, \mathrm{K} \alpha)$, and sanidine $(\mathrm{K}, \mathrm{K} \alpha)$. The following diffracting crystals were selected: TAP for $\mathrm{Na}, \mathrm{Mg}$, and $\mathrm{Al}$, PETJ for $\mathrm{K}, \mathrm{Si}$, and $\mathrm{Ca}$, and $\mathrm{LIFH}$ for $\mathrm{Ti}, \mathrm{Cr}, \mathrm{Mn}$, 
and Fe. The detection limits were automatically calculated by the Jeol microprobe software version JXA8200 and they are listed in the following as ppm: Na, Al, Mg, K, Ca (100), Si, Cr, Fe, Mn (150), and $\mathrm{Ti}$ (200). As a consequence of the severe ocean-floor hydrothermal alteration that affected the studied rocks, a few samples were suitable for electron microprobe analysis. Only one type of mineral phase (plagioclase or clinopyroxene) was fresh enough to be analyzed in only three samples of the sheeted dyke and volcanic complexes. In four samples from the intrusive complex, we found two or more different types of fresh mineral phases, including olivine, plagioclase, and clinopyroxene. The composition of $\mathrm{Fe}^{2+}$ and $\mathrm{Fe}^{3+}$ for clinopyroxene was calculated from the measured FeO according to the method of Droop [62]. Representative analyses are shown in Supplementary Tables S4-S6.

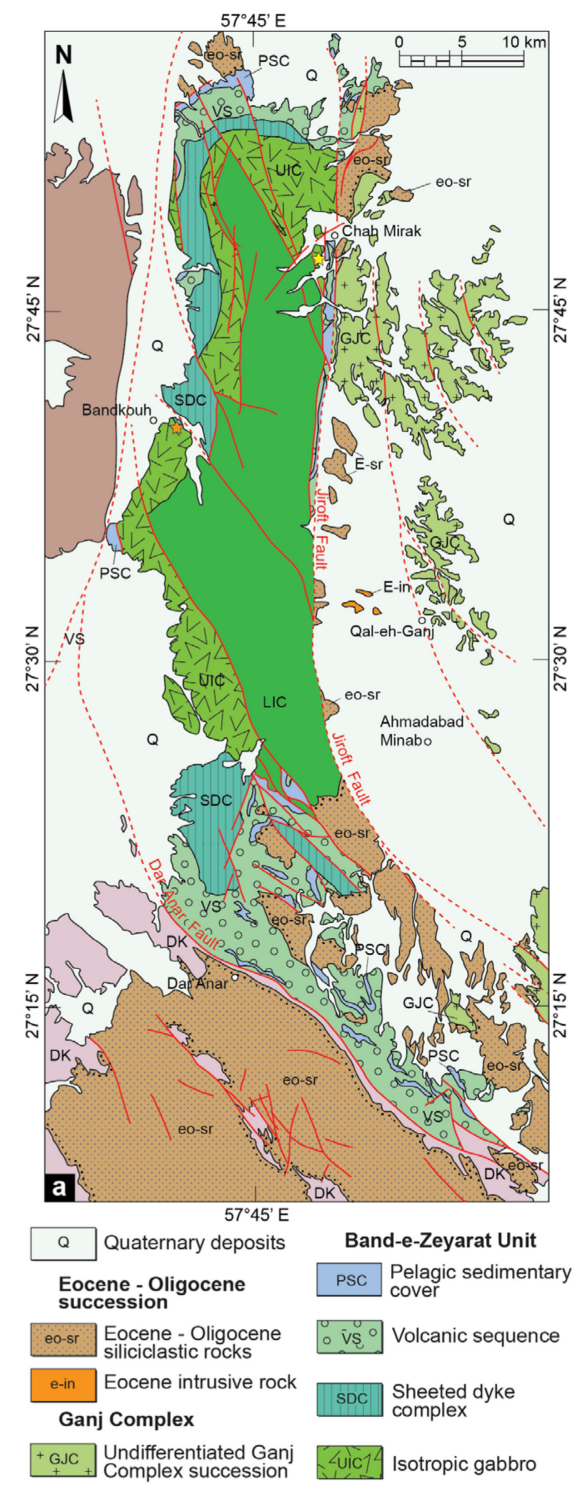

\section{b Band-e-Zeyarat ophiolite}
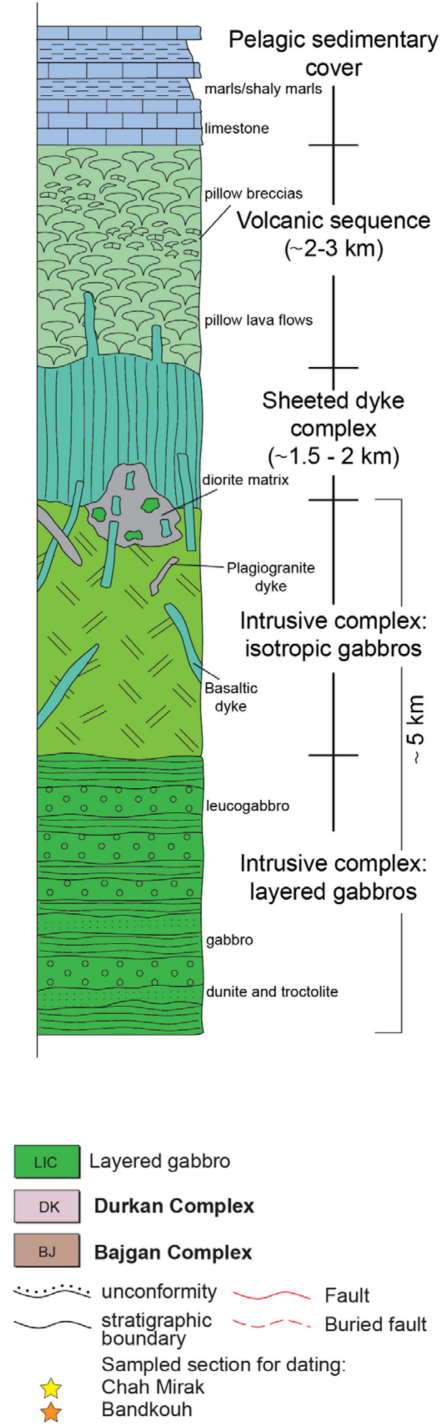

Figure 2. (a) Simplified geological map of north-western sector of the North Makran domain showing the structural setting of the Band-e-Zeyarat ophiolite (based on Samimi Namin [37] and modified according to our original fieldwork and photointerpretation with satellite images). (b) Schematic stratigraphic column of the Band-e-Zeyarat ophiolite.

\subsection{Zircon $\mathrm{U}-\mathrm{Pb}$ Geochronology}

We analyzed zircon grains separated from the quartz-diorites MK748 and MK749 as well as from the plagiogranites MK422 and MK423. Zircons were handpicked from the heavy mineral fraction, 
placed into epoxy resin mounts, and polished to expose the zircon cores. Prior to U-Pb radiometric dating, the internal structure of detrital zircons was imaged using cathodoluminescence (CL) at the Institute of Geosciences and Earth Resources of the National Research Council (IGG-CNR) of Pavia (Italy). Representative CL images of zircon grains are shown in Supplementary Figure S1. In situ U-Pb geochronology was determined by excimer Laser-ablation Inductively-Coupled-Plasma Mass-Spectrometry LA-ICP-MS at CNR-IGG of Pavia. The LA instrument couples an ArF excimer laser microprobe at $193 \mathrm{~nm}$ (Geolas200Q-Microlas) with Triple Quadrupole ICP-MS 8900 Agilent (Agilent, Santa Clara, CA, USA). Ablation was undertaken in helium flowing at $0.541 \mathrm{~min}^{-1}$, which was mixed with argon flowing at $0.841 \mathrm{~min}^{-1}$ immediately after leaving the ablation cell. ICP-MS tuning was performed using a 50-micron diameter on the NIST610 glass at $8 \mathrm{~J} \mathrm{~cm}^{-2}$ laser fluence. The ICP-MS was tuned for low oxides (ThO/Th $<0.2 \%$ ) maximizing sensitivity for heavy masses $\left({ }^{238} \mathrm{U}\right)$ and $\mathrm{U} / \mathrm{Th}$ of about 1 . Zircons were analyzed using a 25 -micron laser beam fired at $5 \mathrm{~Hz}$ and a fluence of $8.0 \mathrm{~J} \mathrm{~cm}^{-2}$. Each analysis consisted of a $40 \mathrm{~s}$ gas blank followed by a $60 \mathrm{~s}$ ablation. Masses monitored were ${ }^{202} \mathrm{Hg},{ }^{204} \mathrm{~Pb},{ }^{206} \mathrm{~Pb},{ }^{207} \mathrm{~Pb},{ }^{208} \mathrm{~Pb},{ }^{232} \mathrm{Th},{ }^{235} \mathrm{U}$, and ${ }^{238} \mathrm{U}$. The ${ }^{235} \mathrm{U}$ signal is calculated from ${ }^{238} \mathrm{U}$ on the basis of the ratio ${ }^{238} \mathrm{U} /{ }^{235} \mathrm{U}=137.818$ [63]. Laser-induced $\mathrm{U}-\mathrm{Pb}$ fractionation and mass discrimination effects were simultaneously corrected using a matrix-matched external standard and considering the same integration intervals on the standard and the unknowns. The reference zircon GJ-1 (608.5 $\pm 0.4 \mathrm{Ma}$ [64]) was adopted as an external standard. For means of quality control, the reference zircons 91,500 (1065.4 $\pm 0.6 \mathrm{Ma}$ [65]) and Plešovice (337.1 $\pm 0.4 \mathrm{Ma}$ [66]) were also analyzed as unknown. Data reduction was carried out with the GLITTER software package version 4.4.4 [67]. IsoplotR software version 4.0.2 [68] was used for data processing and plotting. We performed $69 \mathrm{U}-\mathrm{Pb}$ analyses on 58 zircon grains and the results are listed in Supplementary Table S7.

\section{Stratigraphy of the Band-e-Zeyarat Ophiolite}

The Band-e-Zeyarat ophiolite is bordered by regional-scale strike-slip and reverse fault zones (Figures $1 \mathrm{c}$ and 2a) [20,47]. It has classically been considered as a unique and coherent tectonic unit $[17,24,47]$. However, it represents a N-S elongated tectonic element in the western North Makran domain, whose continuity is crosscut by several high-angle and mainly strike-slip fault zones (Figures 1c and 2a). These fault zones also involved the post-Eocene siliciclastic successions, which unconformably cover the Band-e-Zeyarat unit (Figures 1c and 2a). Therefore, it is not possible to clearly understand if the post-Eocene tectonic activity of these faults juxtaposed different ophiolitic units or if these faults only interrupted the N-S continuity of a unique ophiolitic unit.

The Band-e-Zeyarat ophiolite includes, from bottom to top: (1) a rather thick $(\sim 5 \mathrm{~km})$ intrusive complex consisting of layered gabbros (in the lower part) that gradually pass upward to isotropic gabbros, (2) a sheeted dyke complex ( 1.5-2 km), and (3) a volcanic sequence up to $\sim 2-3 \mathrm{~km}$ thick (Figure $2 b$ ). In addition, a mainly carbonatic, pelagic sedimentary cover stratigraphically overlays the volcanic sequence (Figure $2 b$ ). The layered gabbros consist of cumulitic rocks including alternating troctolites, olivine-gabbros, leucogabbros, as well as minor dunites (Figure 2b). This alternation defines $\mathrm{a} \mathrm{cm}$ - to $\mathrm{m}$-thick magmatic layering (Figures $2 \mathrm{~b}$ and $3 \mathrm{a}$ ). In addition, the gabbros show a well-developed magmatic foliation, which can be readily recognized in the field and it is defined by the iso-orientation of the mineral assemblages, especially plagioclase and pyroxene (Figure 3b). The isotropic gabbro series mainly consist of isotropic rocks, but cumulitic layers are locally found. This series includes gabbros, olivine-gabbros, ferrogabbros, and diorites (Figures $2 \mathrm{~b}$ and $3 \mathrm{c}$ ). In addition, small plagiogranitic bodies and dykes can be observed in this series (Figure 2b). Plagiogranites are, however, particularly abundant at the top of the intrusive complex, close to the transition between gabbros and the sheeted dyke complex. In addition, the isotropic gabbros are frequently crosscut by basaltic dykes, which are particularly abundant at the top of the series (Figure $2 b$ ). The sheeted dyke complex consists of mutually intrusive, parallel, and sub-parallel dykes showing different colors and grain sizes (Figure 3d). Their contacts are usually tectonized and fractured, then chilled margins are rarely preserved. Dykes show variable thickness, from pluridecimetric to plurimetric, and are typically characterized by 
doleritic texture that can usually be easily recognized in the field (Figure 3e). The volcanic sequence stratigraphically overlays the sheeted dyke complex through a transitional zone composed of pillow lavas and massive lava flows cut by abundant sills and dykes (Figure 2b). The volcanic sequence is characterized by alternating pillow lava flows up to plurimetric in thickness (Figure 3f) and minor massive lava flows. In addition, pillow breccias are also interlayered in the sequence at several stratigraphic levels (Figure 2b). They consist of centimetric- to pluridecimetric-sized fragments of pillow basalts as well as pelagic limestones and cherts, which are set in a fine-grained glassy matrix (Figure 3g). Finally, the volcanic sequence is crosscut by randomly distributed individual dykes. The sedimentary cover consists of alternating whitish- to brownish-pelagic limestones, shaly marls and shales, as well as minor abundant pinkish limestones and red cherts (Figures $2 \mathrm{~b}$ and $3 \mathrm{~h}$ ). In addition, tabular beds of turbiditic limestone are interlayered in the sequence.
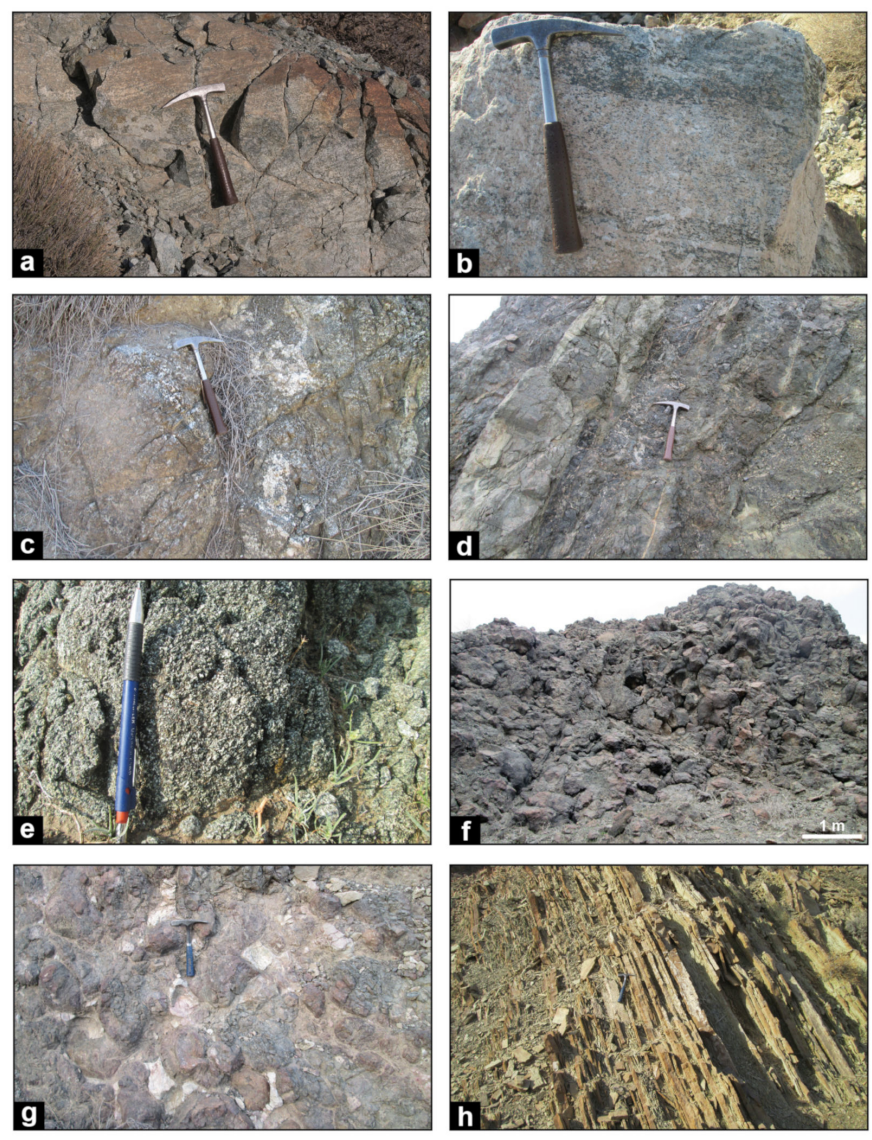

Figure 3. Field occurrence of the Band-e-Zeyarat ophiolite: (a) cumulitic gabbros from the layered gabbro, (b) close up of primary magmatic banding defined by the alternation of leucogabbro and gabbro, (c) gabbro from the isotropic gabbro, (d) vertical and parallel dykes from the sheeted dyke, (e) close up of the doleritic texture of an individual dyke from the sheeted dyke, (f) pillow lava flows from the volcanic sequence, (g) pillow breccia with clasts of whitish limestone, and (h) alternating thin beds of limestone and marl from the pelagic sedimentary cover.

\section{Sections Sampled for Plagiogranites Suitable for Zircon U-Pb Geochronological Dating}

The best plagiogranite outcrops can be found at the transition between the gabbro and sheeted dyke complexes in the Chah Mirak and Bandkouh areas (Figure 2a). In the Chah Mirak section, the upper part of the intrusive complex is well-exposed and is crosscut by both mafic and plagiogranite dykes (Figure $4 a, b$ ). Two samples of plagiogranites were taken for geochronological analysis (samples MK422 and MK423). Mafic dykes are intruded into isotropic ferrogabbros (sample MK455) and are up to $\sim 2 \mathrm{~m}$ thick (Figure $4 \mathrm{a}, \mathrm{b}$ ). They are characterized by porphyritic texture and show chilled margin, 
indicating intrusion in relatively cold gabbros. In contrast, the plagiogranite dykes show up to metric thickness and crosscut both gabbros and mafic dykes (Figure 4a,b). Plagiogranite dykes are commonly intruded along the contacts between gabbros and mafic dykes (Figure $4 a, b)$. Plagiogranite injections caused fragmentation of both gabbros and mafic dykes, producing a breccias in which plagiogranite forms the matrix enclosing fragments of both gabbros and mafic dykes (Figure 4c). These fragments are centimetric in size and show sub-angular to rounded margins (Figure 4c). In the thin section, the contact between plagiogranites and mafic dyke clasts is rather transitional, not sharp, and shows a gradual decrease in grain size toward the clasts (Figure $4 \mathrm{~d}$ ).
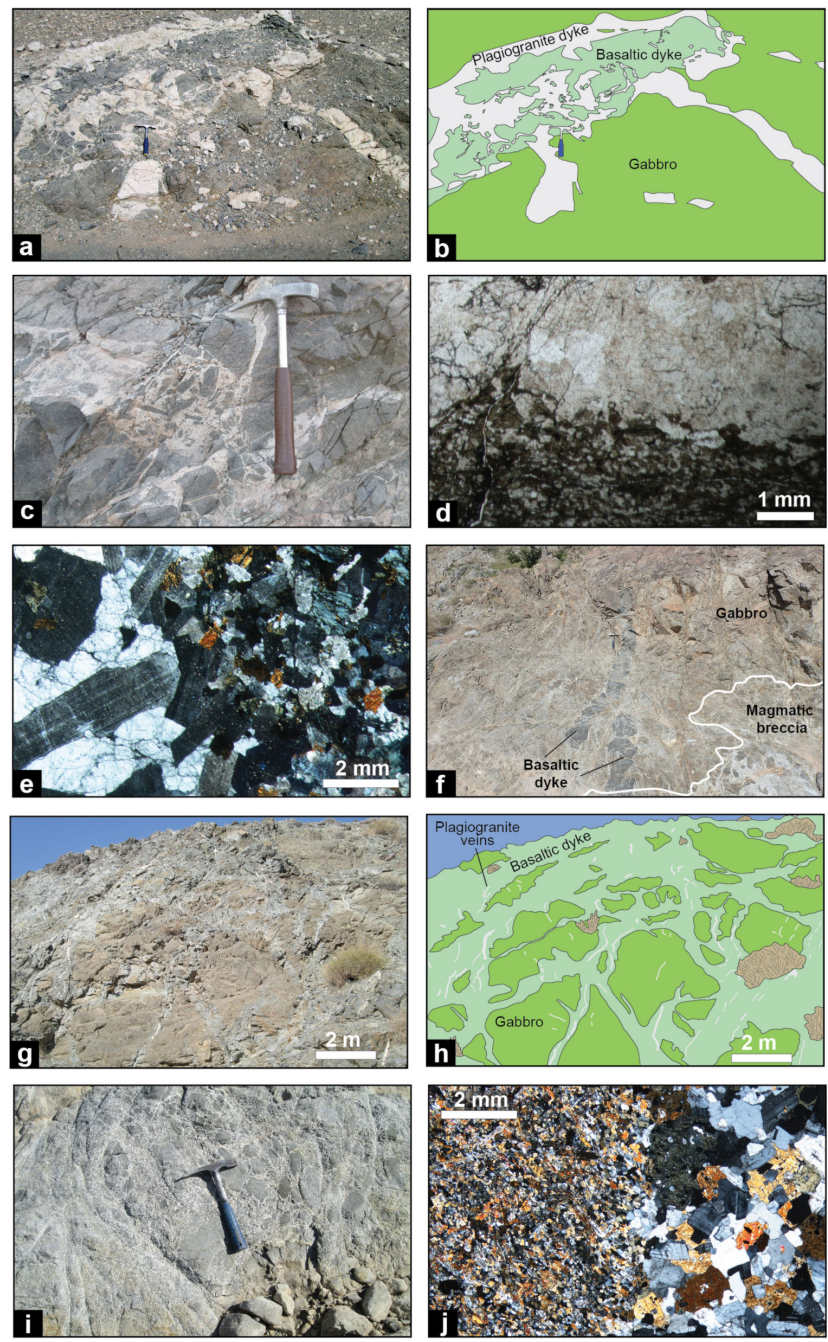

Figure 4. Field occurrence and photomicrographs of the sections sampled for zircon dating. (a-e) Chah Mirak section: (a) view and (b) schematic sketch of the complex intrusive relationships between isotropic gabbro, mafic dyke, and plagiogranite dyke (hammer for scale). (c) Magmatic breccia showing plagiogranite matrix enclosing sub-angular to rounded clasts of both gabbro and mafic dyke (hammer for scale), (d) photomicrographs of the contact between matrix and clasts in the magmatic breccia, (e) photomicrographs of the curviplanar contact between the plagiogranite and the gabbro. $(\mathbf{f}-\mathbf{j})$ Bandkouh section: (f) view and (g) schematic explanatory drawing of the transition zone between the isotropic gabbro and the sheeted dyke showing a network of basaltic dykes crosscutting the gabbro screen. White plagiogranite veinlets crosscut both the gabbro and the dykes, (h) magmatic breccia bodies within the gabbro (hammer for scale), (i) close-up view of the magmatic breccia showing sub-angular to rounded clasts set within plagiogranite matrix. Plagiogranite veinlets are injected in the clasts from the matrix (hammer for scale), (j) gradual intrusive contact between plagiogranite matrix and micro-gabbro clasts in the magmatic breccia. 
The contact between the plagiogranite dykes and the gabbros is rather sharp but curviplanar. A decrease in the grain size of plagiogranites toward the contact is locally observed (Figure 4e). The relationships between plagiogranites and mafic dykes, as well as the nature of their contacts, suggest that the plagiogranite dykes were emplaced after the mafic dykes, but when the latter were still able to react to the intrusion of the plagiogranite with a ductile behavior. These data collectively support the primary magmatic relationships between the sampled plagiogranites and the intrusive complex.

In the Bandkouh section, the base of the sheeted dyke complex is characterized by the occurrence of magmatic breccia showing a matrix of plagiogranitic to quartz-dioritic composition (Figure $2 b$ ). Samples MK748 and MK749 used for geochronological dating consist of quartz-diorites taken from the matrix of this breccia. The lower part of this section shows lens-shaped bodies of magmatic breccias, which can reach up to tens of meters in thickness (Figure 4f). The upper part of this section is characterized by a network of mafic dykes crosscutting the gabbro screens (Figures $2 \mathrm{~b}$ and $4 \mathrm{~g}$, $\mathrm{h}$ ). Dykes gradually increase in abundance upward and progressively replace the gabbros to form a pure sheeted dyke complex. The magmatic breccias show anastomosed contacts with the gabbros (Figure 4f), and consist of plagiogranite matrix, which enclose up to metric enclaves of gabbros and mafic dykes (Figure 4i). The mafic enclaves show lobate to sub-angular shape, and their margins are quite sharp, but generally rounded (Figure 4i). The enclaves are locally cut by a network of millimetric veins of plagiogranite, which are clearly injected from the matrix (Figure 4i). In this case, the contacts between veins and enclaves are curviplanar with no clear grain variation and chilled margin (Figure 4j). In addition, in this portion of the transition zone, the gabbros are characterized by small $(<\mathrm{few} \mathrm{cm})$ veins of plagiogranite that are clearly injected into the gabbros from the breccia matrix. These observations suggest a primary magmatic relationship between plagiogranites and mafic rocks. Plagiogranite melts were localized in the uppermost part of the intrusive complex and were injected into the transition zone between the intrusive and the sheeted dyke complexes. This process produced magmatic breccias and plagiogranite veinlets into the already crystallized but likely still hot gabbros. Similar magmatic breccias are found in the Oman ophiolites at the transition between the intrusive and sheeted dyke complexes, as well as in other ophiolitic complex. They have been interpreted as forming in a typical mid-oceanic ridge magma chamber, in consequence of the interaction of coeval different magmatic liquids $[69,70]$.

\section{Petrography of the Magmatic Rocks}

Most of the studied rocks are affected by various degrees of low-grade ocean-floor hydrothermal alteration. Alteration has produced the replacement of the primary igneous phases, whereas the primary igneous textures are always well preserved. In general, olivine is completely replaced by iddingsite and/or serpentine in volcanic and subvolcanic rocks, whereas it is preserved only in intrusive rocks. Plagioclase is commonly pseudomorphosed by albite and/or phyllosilicate aggregates, even though some samples of intrusive rocks show fresh plagioclase. Clinopyroxene alteration normally occurs as pseudomorphic replacement by brown amphibole. This is more common in volcanic and subvolcanic rocks, whereas fresh pyroxene generally occurs in the intrusive rocks. However, rims of crystals are locally replaced by amphibole also in the intrusive rocks. The volcanic glass in the groundmass of volcanic rocks is commonly replaced by fine-grained assemblages of chlorite and clay minerals.

In the layered intrusive complex, rocks are characterized by holocrystalline, medium- to coarse-grained, cumulitic texture. They range in composition from dunites to troctolites, olivine-gabbros, gabbros, and leucogabbros. Dunites consist of completely serpentinized olivine crystals, usually bordered by oxide rims (Figure 5a). In addition, relicts of altered clinopyroxene occur and they likely represent inter-cumulus phases. Troctolites show rounded olivine crystals $(40 \%-60 \%)$, subhedral plagioclase $(60 \%-40 \%)$, together with minor clinopyroxenes and rare altered spinels (Figure $5 \mathrm{~b}$ ). Plagioclase crystals locally enclose olivine, whereas anhedral clinopyroxene crystals occur in interstitial spaces (Figure 5b). The crystallization order is: olivine + plagioclase + clinopyroxene, which is the typical crystallization order of MORB-type rocks [71]. 

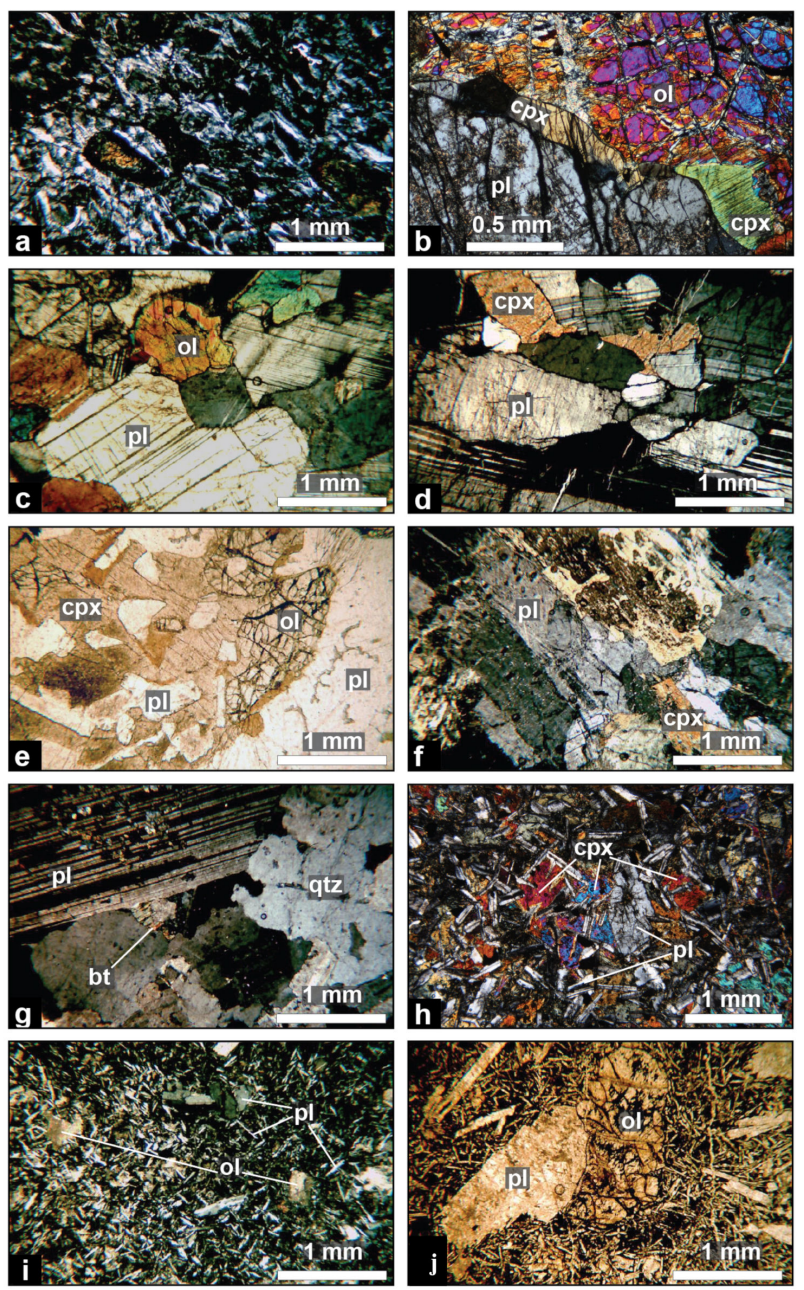

Figure 5. Photomicrograph of intrusive $(\mathbf{a}-\mathbf{g})$, subvolcanic $(\mathbf{h})$, and volcanic $(\mathbf{i}, \mathbf{j})$ rocks from the Band-e-Zeyarat ophiolite: (a) serpentinized dunites showing relicts of magmatic olivine, (b) cumulitic texture in troctolite showing large olivine and plagioclase crystals and inter-cumulus clinopyroxene, (c) cumulitic texture in gabbro showing rounded olivine crystals and subhedral plagioclase, (d) cumulitic leucogabbro showing inter-cumulus clinopyroxene and magmatic foliation defined by preferential orientation of plagioclase crystals, (e) ipidiomorphic texture in gabbro showing crystallization order olivine + plagioclase + clinopyroxene, (f) autoallotriomorphic texture showing subhedral plagioclase and clinopyroxene, (g) euhedral plagioclase and anhedral quartz in plagiogranite, (h) subophitic texture in basaltic dyke from the sheeted dyke, (i) aphyric and weakly porphyritic (j) pillow lava showing intersertal texture with plagioclase microlites set in altered volcanic glass.

Gabbros range from olivine-gabbros to gabbros and leucogabbros according to the modal contents of olivine and plagioclase. Olivine crystals (from 10\% to 30\% in volume) show rounded shape and are surrounded by subhedral plagioclases (Figure $5 \mathrm{c}$ ) and anhedral clinopyroxene. In addition, subordinate Fe-Ti oxides also occur in interstitial positions. Leucogabbros are composed by subhedral plagioclase (70\%-80\% of the modal composition) and interstitial clinopyroxene (30\%-10\%) (Figure $5 \mathrm{~d}$ ), as well as subordinate olivine and spinel $(<10 \%)$. They commonly show magmatic foliation defined by the parallel orientation of plagioclase laths (Figure 5d). The rocks from the isotropic complex show a wide range of variation in grain-size, from coarse- to fine-grained. They include gabbros, ferrogabbros and diorites showing granular texture ranging from ipidiomorphic to autoallotriomorphic. Ipidiomorphic gabbros show euhedral olivine, often enclosed in subhedral plagioclase crystals (Figure 5e). In addition, large (i.e., plurimillimetric) clinopyroxene oikocrysts enclose both olivine and plagioclase (Figure 5e), defining the crystallization order as: olivine + plagioclase + clinopyroxene. Autoallotriomorphic 
textures are characterized by subhedral plagioclase and clinopyroxene and minor olivine (Figure 5f). The ferrogabbros typically show interstitial Fe-Ti oxides, whereas diorites have biotite and rare quartz in interstitial position. The plagiogranite dykes are medium-grained and show holocrystalline and ipidiomorphic texture (Figure 5g). They are composed of euhedral plagioclase, surrounded by anhedral quartz and minor amphibole (Figure 5g), usually pseudomorphosed by chlorite. In addition, rare small crystals of epidote, biotite, and zircon occur in interstitial position.

Basaltic dykes, either individual dykes in the intrusive complex or sheeted dykes, show mediumto fine-grained holocrystalline texture. Commonly, these rocks are characterized by subophitic texture with plagioclase laths partially enclosed within clinopyroxene crystals, as well as interstitial Fe-Ti oxides and rare altered olivine crystals (Figure 5h). Some samples show intergranular texture with plagioclase laths and granular clinopyroxene. Basaltic pillow lavas show both aphyric and weakly porphyritic (PI 10) textures (Figure 5i,j). The aphyric varieties are hypocrystalline and show intersertal texture with plagioclase laths and minor olivine set in an altered volcanic glass (Figure 5i). In contrast, the porphyritic basaltic rocks show plagioclase and olivine phenocrysts, up to $3 \mathrm{~mm}$ in size, set in a hypocrystalline groundmass (Figure 5j). The groundmass commonly shows intersertal texture with plagioclase laths and olivine microlites surrounded by altered volcanic glass (Figure 5j). Few samples also show amygdaloidal texture defined by rounded vesicles filled by calcite.

\section{Geochemistry of the Magmatic Rocks}

The description of the geochemical features of the magmatic rocks studied in this paper is based on those elements considered virtually immobile during alteration processes [7,72]. They include some incompatible elements (e.g., Ti, P, Zr, Y, Nb, Ta, Hf, Th), middle (MREE) and heavy (HREE) rare earth elements (REE), as well as some transitional metal, such as $\mathrm{Ni}, \mathrm{Cr}, \mathrm{V}$, and Co. In contrast, light REE (LREE), large ion lithophile elements (LILE, e.g., $\mathrm{Ba}, \mathrm{Sr}, \mathrm{Rb}$ ), and most major elements are usually sensitive to secondary alteration processes. Therefore, we plotted these elements against immobile elements (e.g., Zr or Y) and we calculated the correlation coefficients in order to check their amount of mobilization (not shown). These tests returned fairly good correlation for LILE, CaO, and MgO in most of the samples, suggesting that these elements can be used, though with some caution. In contrast, the good correlation coefficients for LREE suggest no or very little re-mobilization of these elements during secondary alteration processes.

\subsection{Intrusive Complex}

Cumulitic rocks range from dunites to troctolites, olivine-gabbros, gabbros, and leucogabbros, whereas the isotropic varieties include gabbros, ferrogabbros, diorites, quartz-diorites, and plagiogranites (Supplementary Table S2). The large variation in the geochemistry of these rocks suggests that they were formed at different stages of magmatic fractionation. In fact, the variation of their geochemistry is in accordance with the variation of the modal composition, as also evidenced by the co-variation of $\mathrm{Al}_{2} \mathrm{O}_{3} / \mathrm{TiO}_{2}$ against Ti/1000 (assumed here as an indicator of differentiation) shown in Figure 6 . In this figure and in agreement with petrographic observations, the intrusive rocks plot along a differentiation trend defined by the crystallization of olivine + plagioclase + clinopyroxene + magnetite (Figure 6), which is the typical crystallization order of tholeiitic magma series with mid-oceanic ridge (MOR) affinity [66].

Ultramafic cumulates and troctolites display low $\mathrm{TiO}_{2}, \mathrm{P}_{2} \mathrm{O}_{5}$, and incompatible element contents, such as $\mathrm{Nb}, \mathrm{Y}$, and $\mathrm{Zr}$, whereas $\mathrm{MgO}, \mathrm{Cr}, \mathrm{Co}$, and $\mathrm{Ni}$ contents are particularly high (Supplementary Table S2). The troctolites MK750 and MK781 display a wide range of variation in the contents of $\mathrm{Al}_{2} \mathrm{O}_{3}$ (5.50-10.60 wt.\%), $\mathrm{MgO}$ (23.50-32.07 wt.\%), $\mathrm{CaO}(4.20-8.00$ wt.\%), and $\mathrm{Cr}$ (683-1926 ppm), which are depending on the mutual abundance of plagioclase and olivine, as observed by the petrographic study. Ultramafic cumulates consist of dunites with high MgO (37.83-38.03 wt.\%) and Cr (2287-3146 ppm). The dunite MK47 shows severe depletion in incompatible elements (about 0.01 times N-MORB composition) and REE (about 0.1 times Chondrite abundance (Figure 7a,b)). 
In contrast, dunite MK40 shows comparatively higher incompatible elements and REE contents, which are broadly comparable to those of the cumulitic gabbros (Figure 7a). Both dunite samples do not show any Eu anomaly (Figure $7 \mathrm{~b}$ ). Cumulitic gabbros show a wide range of variation in the contents of many major and trace elements, which clearly reflect the variation of the modal amounts of rock-forming minerals. In particular, $\mathrm{Al}_{2} \mathrm{O}_{3}(14.50-23.60 \mathrm{wt} . \%), \mathrm{MgO}$ (7.50-17.34 wt.\%), and $\mathrm{Cr}$ (337-1927 ppm) are among those elements showing the largest variations. $\mathrm{Mg \#}(\mathrm{Mg \#}=100 \times \mathrm{MgO} /(\mathrm{MgO}+\mathrm{FeO}))$ is also variable (91-76), but generally high (around 84 in most samples). In contrast, $\mathrm{TiO}_{2}, \mathrm{P}_{2} \mathrm{O}_{5}$, and other incompatible elements' contents are low, showing values of far lower than 1 times N-MORB composition [73]. In the chondrite-normalized REE diagram, all gabbroic rocks show marked Eu-positive anomalies (Figure $7 \mathrm{~b}$ ), reflecting large amounts of plagioclase early crystallization and accumulation (Figure 6). The REE patterns for the leucogabbros and gabbros MK32 and MK35 are quite flat, with slight LREE and MREE enrichment with respect to HREE (Figure $7 \mathrm{~b}$ ), as testified by $(\mathrm{La} / \mathrm{Yb})_{\mathrm{N}}$ and $(\mathrm{Sm} / \mathrm{Yb})_{\mathrm{N}}$ ratios slightly higher than 1 (Supplementary Table S2). In contrast, gabbro MK44 shows an LREE-depleted pattern that is comparable with the REE patterns of typical N-MORB [73].

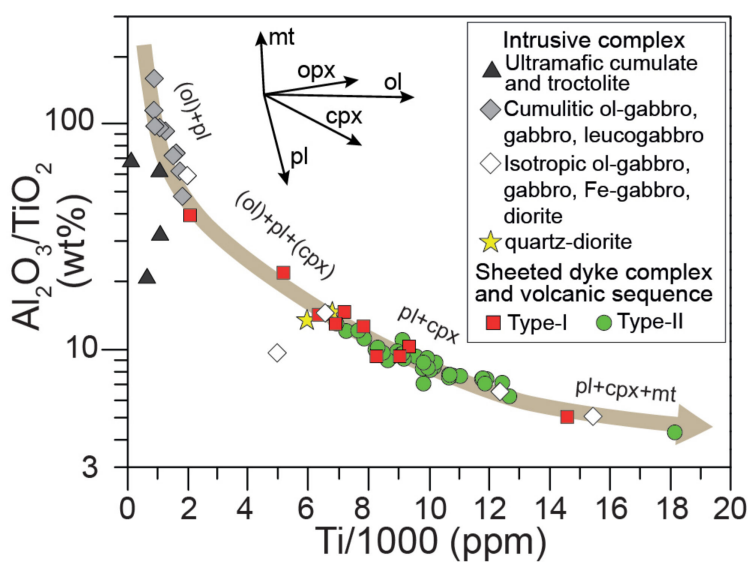

Figure 6. $\mathrm{Al}_{2} \mathrm{O}_{3} / \mathrm{TiO}_{2}$ vs. Ti/1000 diagram for magmatic rocks from the Band-e-Zeyarat ophiolite. Arrows show the fractional crystallization trends of magnetite (mt), orthopyroxene (opx), olivine (ol), clinopyroxene (cpx), and plagioclase (pl).
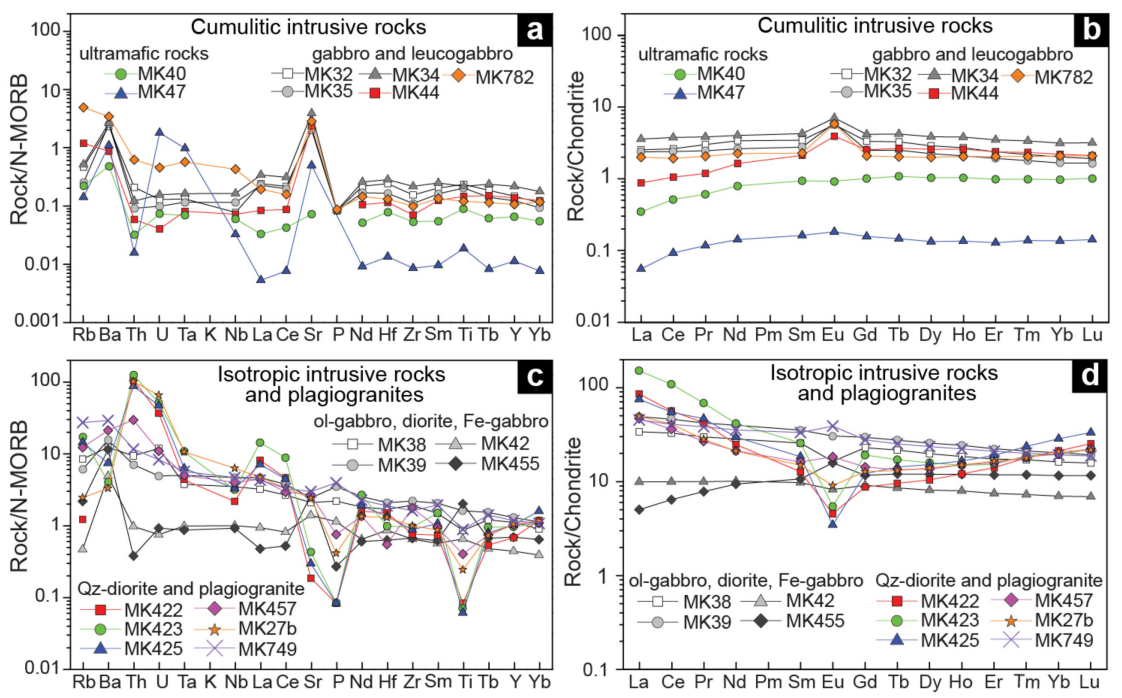

Figure 7. N-MORB (normal-type mid-ocean ridge basalt)-normalized incompatible element patterns $(\mathbf{a}, \mathbf{c})$ and chondrite-normalized rare earth element (REE) patterns (b,d) for mafic and ultramafic cumulates, isotropic mafic rocks, quartz-diorites, and plagiogranites from the intrusive complex of the Band-e-Zeyarat ophiolite. Normalizing values are from Sun and McDonough [73]. 
The isotropic mafic rocks range from gabbro to ferrogabbro and diorite with $\mathrm{Mg} \#$ ranging from 83 to 51. They show a wide variation of $\mathrm{TiO}_{2}, \mathrm{P}_{2} \mathrm{O}_{5}, \mathrm{Zr}, \mathrm{Nb}$, and $\mathrm{Y}$ contents, likely reflecting different progressive degrees of fractionation (Supplementary Table S2, Figure 6). This is also suggested by the high variation of compatible elements' contents, such as $\mathrm{Cr}, \mathrm{Co}$, and $\mathrm{Ni}$ (Supplementary Table S2). In addition, $\mathrm{V}$ contents are extremely variable in the isotropic intrusive rocks, showing the lowest values in olivine-gabbro and a very high value in the ferrogabbro (Supplementary Table S2). N-MORB-normalized incompatible elements' spider diagrams show two distinct patterns for the isotropic intrusive rocks (Figure 7c). In detail, ferrogabbro MK455 show rather flat patterns, with normalized values lower than 1 times N-MORB composition (Figure 7c), whereas the olivine-gabbro MK42 and diorites MK38 and MK39 display a regularly decreasing pattern from LILE to HFSE (high field strength elements) (Figure 7c).

Accordingly, ferrogabbro MK455 shows a chondrite-normalized REE pattern with marked depletion of LREE, with respect to MREE and HREE (Figure 7d). Samples MK42, MK38, and MK39 show a REE pattern gradually decreasing from LREE to HREE (Figure 7d). Different extents of negative anomalies of Eu are observed in all these samples, likely reflecting different amounts of early crystallization and fractionation of plagioclase (Figure 7d).

The plagiogranitic rocks range in composition from quartz-diorites $\left(\mathrm{SiO}_{2}=56.50-58.30 \mathrm{wt} . \%\right.$; $\mathrm{Mg} \#=61-49)$ to highly differentiated plagiogranites $\left(\mathrm{SiO}_{2}=63.60-74.20 \mathrm{wt} . \%, \mathrm{Mg} \#=56-32\right)$. Accordingly, the contents of many major and trace elements show a wide range of variation. For example, $\mathrm{TiO}_{2}, \mathrm{P}_{2} \mathrm{O}_{5}, \mathrm{MgO}, \mathrm{Ni}, \mathrm{Cr}$, and Co contents are relatively high in the quartz-diorites and very low in plagiogranites (Supplementary Table S2). In the N-MORB-normalized incompatible elements' spider diagrams, plagiogranites show different patterns (Figure 7c). The majority of the samples show different extents of $\mathrm{Ti}, \mathrm{P}$, and $\mathrm{Nb}$ negative anomalies, as well as LILE enrichment with respect to HFSE. HFSE display rather low values ranging from 0.8 to 1.9 times N-MORB composition (Figure 7c). In the chondrite-normalized REE diagram (Figure 7d), the quartz-diorite MK749 displays a regularly decreasing pattern from $\mathrm{La}$ to $\mathrm{Yb}$, whereas the plagiogranites show U-shaped patterns with MREE depletion with respect to LREE and HREE, which is likely associated with the fractional crystallization of amphibole. In addition, most of the samples display Eu-negative anomalies (Figure 7d), suggesting abundant crystallization and removal of plagioclase before their formation.

In conclusion, the geochemistry of the cumulitic rocks from the Band-e-Zeyarat ophiolite is mainly controlled by the amount of cumulus minerals and, therefore, does not represent the composition of a magmatic liquid. Nonetheless, the overall geochemical features of these rocks point out crystallization and mineral removal from parental liquids with MORB affinity [71]. In contrast the chemistry of isotropic gabbros most likely reflect the composition of magmatic liquids, as particularly suggested by the REE compositions with HREE composition $>10$ times the chondrite abundance (Figure $7 \mathrm{~d}$ ). The overall geochemical features indicate that some of the studied gabbroic rocks are comparable with the composition of N-MORBs (MK431 and MK455), whereas some other intrusive rocks have compositions similar to those of enriched-type MORB (E-MORB) rocks (MK42, MK38, and MK39).

The overall geochemical features of quartz-diorites and plagiogranites indicate that they represent differentiated products from primitive MORB-type tholeiitic melts, whose composition was similar to those of the Band-e-Zeyarat basalts. However, plagiogranites represent the product of crystallization of extremely fractionated melts. Therefore, it is impossible to assess if they bear normal-type or enriched-type MORB affinity. In contrast, quartz-diorites MK748 and MK749 show overall geochemical features and REE compositions that are well comparable with those of E-MORB-type rocks (Figure 7d).

\subsection{Sheeted Dyke Complex, Volcanic Sequence, and Individual Dykes}

No geochemical differences can be observed between the individual dykes intruded into the intrusive complex, the dolerites forming the sheeted dyke complex, and the basaltic rocks in the volcanic sequence (Supplementary Table S3); therefore, in this section, we describe together their geochemical features regardless of their distribution in the stratigraphic succession. Subvolcanic and 
volcanic rocks are mainly represented by basalts, minor basaltic andesites and andesites, as well as one rhyolitic dyke (Figure 8). They show variable but relatively low $\mathrm{Nb} / \mathrm{Y}$ ratios that suggest a sub-alkaline nature (Figure 8). $\mathrm{Mg \#} \mathrm{(76.1-40.6),} \mathrm{CaO}$ (2.1-12.5 wt.\%), $\mathrm{Al}_{2} \mathrm{O}_{3}$ (11.4-18.4 wt.\%), MgO (1.2-14.4 wt.\%), $\mathrm{TiO}_{2}(0.35-3 \mathrm{wt} . \%)$, and $\mathrm{P}_{2} \mathrm{O}_{5}(0.06-0.54 \mathrm{wt} . \%)$ are extremely variable, suggesting that these rocks represent melts at different stages of fractionation. This feature is also suggested by the high variability of compatible elements' (e.g., $\mathrm{Cr}, \mathrm{Ni}, \mathrm{Co}$, and V) contents, which generally decrease in abundance from the basalts to the more differentiated basaltic andesites and rhyolites (Supplementary Table S3). In detail, the co-variation diagram of $\mathrm{Al}_{2} \mathrm{O}_{3} / \mathrm{TiO}_{2}$ against $\mathrm{Ti} / 1000$ mainly points out a fractionation trend dominated by the progressive crystallization of olivine, plagioclase, plagioclase + clinopyroxene, and finally, magnetite (Figure 6). This evidence, combined with the low $\mathrm{Nb} / \mathrm{Y}$ ratios, suggests the same sub-alkaline and tholeiitic nature for all the magmatic rocks from the sheeted dyke complex and the volcanic sequence. However, based on incompatible elements and REE compositions, two geochemical types can be distinguished (hereafter Type-I and Type-II). These different geochemical types are observed in both the volcanic sequence and the sheeted dyke complex. However, it is worth to outline that we observed, as a general tendency, that the Type-II rocks are more abundant than Type-I rocks in the upper part of the volcanic sequence.

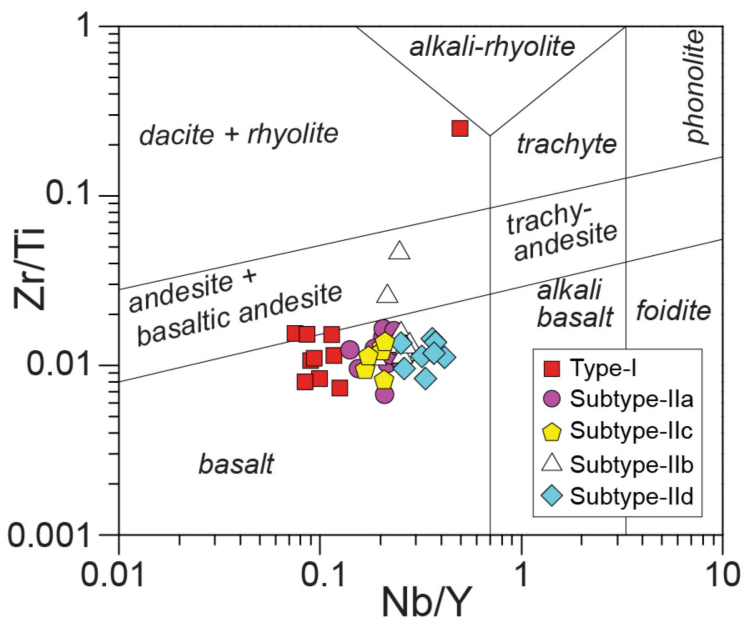

Figure 8. $\mathrm{Nb} / \mathrm{Y}$ vs. $\mathrm{Zr} / \mathrm{Ti}$ discrimination diagram of Winchester and Floyd [74], modified by Pearce [75] for subvolcanic and volcanic rocks from the sheeted dyke complex and volcanic sequence of the Band-e-Zeyarat ophiolite.

\subsubsection{Type-I Volcanic and Subvolcanic Rocks}

Type-I includes basaltic rocks and one rhyolitic dyke (Supplementary Table S3; Figure 8). The basaltic rocks display relatively low $\mathrm{Nb} / \mathrm{Y}$ ratio $(0.08-0.11)$ and they are characterized by generally low abundance of $\mathrm{Y}$ (15.0-50.7 ppm), Zr (55.4-143 ppm), Nb (1.36-5 ppm), Th (0.063-0.611), and Ta (0.090-0.440 ppm) (Supplementary Table S3). The rhyolite MK92 has, in contrast, higher concentration of these incompatible elements, reflecting its differentiated nature (Supplementary Table S3). In the N-MORB-normalized incompatible elements spider diagram (Figure 9a), the basaltic rocks show a rather flat pattern, with slightly positive anomalies in $\mathrm{Ti}$, and low concentration of HFSE and LILE, which range from $\sim 0.35$ to 1.51 and 0.55 to 5 times the N-MORB composition [73], respectively. Chondrite-normalized REE patterns of basaltic rocks (Figure 9b) are rather flat from MREE to HREE, whereas LREE are characterized by variable extent of depletion in comparison with MREE (Figures $9 \mathrm{~b}$ and 10a). These features are exemplified by the $S m_{N} / \mathrm{Yb}_{\mathrm{N}}$ and $\mathrm{La}_{\mathrm{N}} / \mathrm{Sm}_{\mathrm{N}}$ ratios, which are in the range 0.93-1.41 and 0.34-0.97, respectively. Samples MK29 and MK713 show positive Eu anomaly and slightly negative Eu anomaly, respectively (Figure 9b). These features are well comparable with those of typical N-MORB [73]. The rhyolite MK92 is characterized by a marked Eu-negative anomaly, reflecting early crystallization of plagioclase. It shows a rather flat MREE-HREE pattern, with HREE 
contents of $\sim 1.8$ times the chondrite abundance, whereas the LREE are strongly enriched with respect to MREE, as testified by the high $(\mathrm{La} / \mathrm{Sm})_{\mathrm{N}}$ ratios (Figure $9 \mathrm{~b}$; Supplementary Table S3). These geochemical features suggest that the rhyolite can represent the product of differentiation processes of N-MORB-like primary melts. In the discrimination diagram in Figure 10b, the Type-I basalts plot close to the composition of N-MORBs [9], whereas the differentiated rocks (i.e., the basaltic andesites and rhyolite) plot at higher $\mathrm{Nb}_{\mathrm{N}}-\mathrm{Th}_{\mathrm{N}}$ values, along the trend calculated for fractional crystallization starting from an N-MORB primary melt.
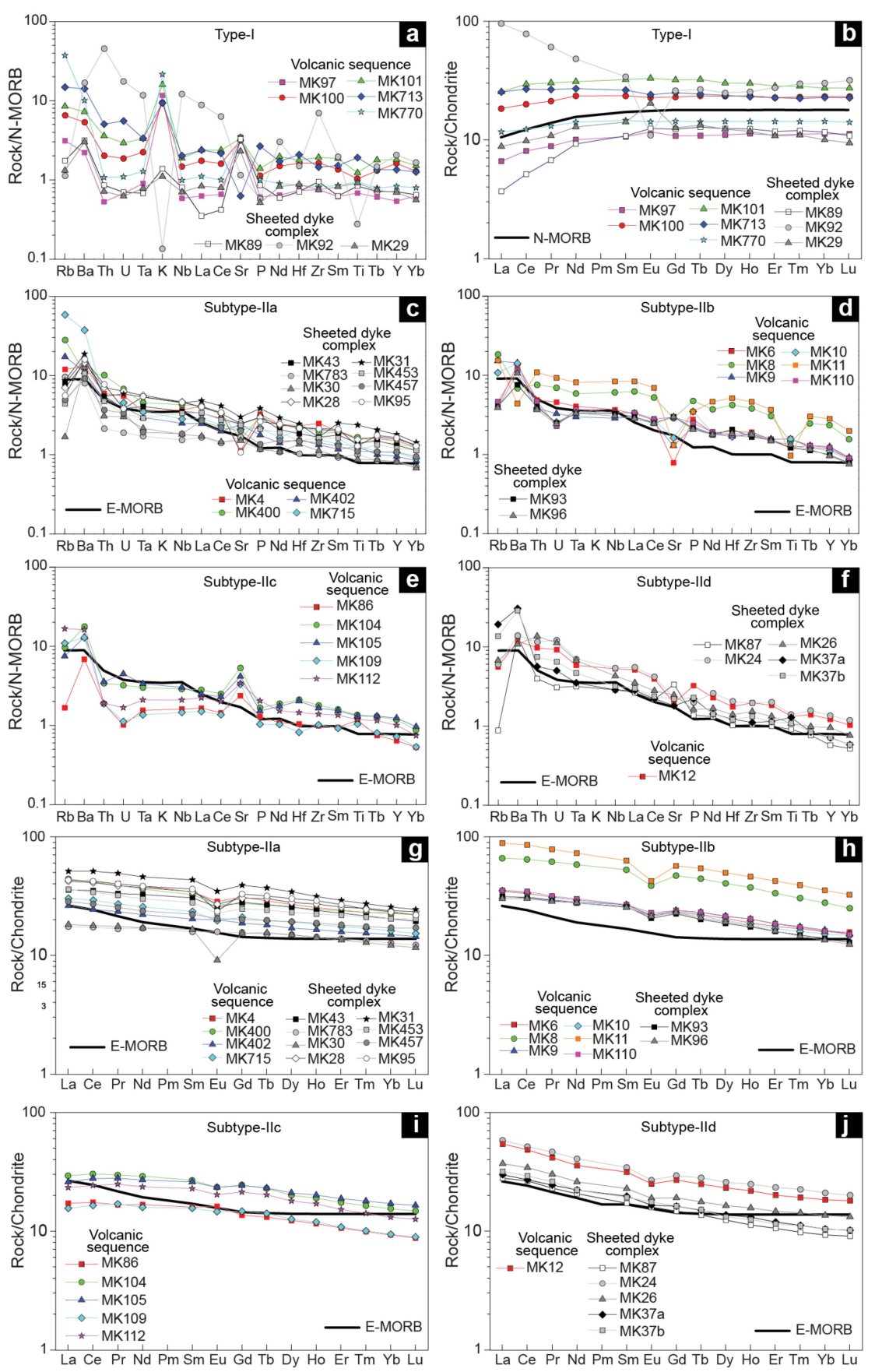

Figure 9. N-MORB (normal-type mid-ocean ridge basalt)-normalized incompatible element patterns $(\mathbf{a}, \mathbf{c}-\mathbf{f})$ and chondrite-normalized rare earth element (REE) patterns $(\mathbf{b}, \mathbf{g}-\mathbf{j})$ for volcanic and subvolcanic rocks from the sheeted dyke complex and volcanic sequence of the Band-e-Zeyarat ophiolite. Normalizing values and N-MORB and E-MORB compositions are from Sun and McDonough [73]. 

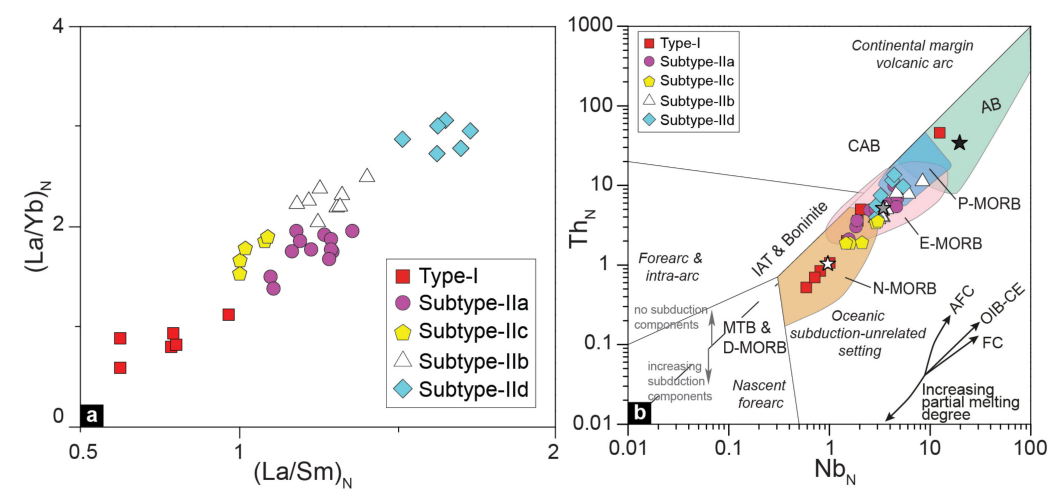

Figure 10. Chondrite-normalized $(\mathrm{La} / \mathrm{Sm})_{\mathrm{N}}$ vs. $(\mathrm{La} / \mathrm{Yb})_{\mathrm{N}}$ diagram $(\mathbf{a})$ and N-MORB-normalized Th vs. $\mathrm{Nb}$ discrimination diagram of Saccani [9] (b) for volcanic and subvolcanic rocks from the sheeted dyke complex and volcanic sequence of the Band-e-Zeyarat ophiolite. Vectors in (b) indicate the trends of compositional variations due to the main petrogenetic processes. Abbreviations: AFC: assimilationfractional crystallization; OIB-CE: ocean island-type (plume-type) component enrichment; FC: fractional crystallization; MORB: mid-ocean ridge basalt; N-: normal type; E-: enriched type; P-: plume type; D-: depleted type; IAT: island arc tholeiite; CAB: calc-alkaline basalt; AB: alkaline oceanic within-plate basalt; MTB: medium titanium basalt. Normalizing values, as well as the composition of typical N-MORB (white star), E-MORB (grey star), and OIB (black star), are from Sun and McDonough [73].

\subsubsection{Type-II Volcanic and Subvolcanic Rocks}

Type-II volcanic rocks include mainly basalts and subordinate basaltic andesites and andesites (Figure 8). Type-II is characterized by Nb/Y ratios ranging from 0.14 to 0.42 (Figure 8). $\mathrm{Nb}$ (3.59-19.46 ppm), $\mathrm{Zr}(72.3-340 \mathrm{ppm}), \mathrm{Th}(0.22-1.31 \mathrm{ppm}), \mathrm{Ta}(0.18-1.07 \mathrm{ppm})$, and $\mathrm{Y}(17.8-78.2 \mathrm{ppm})$ contents are generally higher than those of Type-I rocks.

The N-MORB-normalized incompatible element patterns are characterized by LILE enrichment with respect to HFSE, with regularly decreasing pattern from Th to Y (Figure 9c-f). These elements range from 2 to 14 and 0.5 to 3 times the N-MORB abundance, respectively. Only few differentiated samples display different extents of negative anomalies in Ti, likely reflecting the fractionation of Fe-Ti oxides (Figure 9c,d). The N-MORB-normalized incompatible element patterns (Figure 9c-f) strongly resemble those of the typical E-MORB composition [73]. Accordingly, in the discrimination diagram in Figure 10b, Type-II rocks plot in the field for subduction-unrelated settings, within the compositional field for rocks with E-MORB affinity [73].

The chondrite-normalized REE patterns generally show enrichment of LREE with respect to MREE and HREE with $(\mathrm{La} / \mathrm{Yb})_{\mathrm{N}}=1.3-3.1$ and $(\mathrm{La} / \mathrm{Sm})_{\mathrm{N}}=1.2-1.9$. However, the different samples show crosscutting REE patterns (Figure 9g-j) that, coupled with slightly different incompatible element contents and ratios, point out magmatic differentiation starting from primary melts with distinct REE compositions. These slightly different compositions of primary melts point out, in turn, their origin from partial melting of distinct mantle source compositions and partial melting conditions [67,71]. Therefore, though these geochemical differences are minor, we can distinguish some subtypes of rocks mainly based on REE contents (Figure 10a).

Subtype-IIa basalts show chondrite-normalized REE with Eu-negative anomalies, which are progressively more marked in the relatively more differentiated rocks (Figure 9g). This suggests early fractionation of plagioclase, as commonly observed in tholeiitic volcanic series. These rocks are characterized by gently decreasing patterns from LREE to MREE and HREE (Figure 9g), as exemplified by similar $(\mathrm{La} / \mathrm{Sm})_{\mathrm{N}}$ and $(\mathrm{La} / \mathrm{Yb})_{\mathrm{N}}$ ratios, which are in the range 1.10-1.29 and 1.38-1.87, respectively (Figure 10a). Subtype-IIa basalts can be distinguished from the other Type-II rocks by their relatively high $\mathrm{Ta} / \mathrm{Hf}(>6.3)$ and $\mathrm{Th} / \mathrm{Nb}(>0.07)$ ratios.

Subtype-IIb volcanic rocks and dykes show steeper chondrite-normalized REE patterns with respect to Subtype-IIa (Figure $9 \mathrm{~h})$. In fact, compared to Subtype-IIa rocks, they show similar $(\mathrm{La} / \mathrm{Sm})_{\mathrm{N}}$ 
ratios (1.18-1.40), but higher $(\mathrm{La} / \mathrm{Yb})_{\mathrm{N}}$ ratios, which are in the range 2.04-2.50 (Figure 10a). However, similar to Subtype-IIa, they display Eu-negative anomalies, whose values are positively correlated with the degree of fractionation of the different differentiated rocks. Subtype-IIb basalts can be distinguished from Subtype-IIa basalts by their relatively low $\mathrm{Ta} / \mathrm{Hf}(<6.3)$ and $\mathrm{Th} / \mathrm{Nb}(<0.07)$ ratios. Subtype-IIc basalts show chondrite-normalized REE patterns (Figure 9i) characterized by no or very little enrichment of LREE with respect to MREE, that is, almost flat patterns from La to Sm (Figure 9i). In fact, their $\mathrm{La}_{\mathrm{N}} / \mathrm{Sm}_{\mathrm{N}}$ ratios range from 1.00 to 1.09 (Figure 10a). However, these basalts show moderate LREE/HREE enrichment with $(\mathrm{La} / \mathrm{Yb})_{\mathrm{N}}$ ratios (1.53-1.89) that are comparable to those of Subtype-IIa basalts (Figure 10a). It follows that they display a marked enrichment in MREE with respect to HREE, as exemplified by relatively high $S m_{N} / \mathrm{Yb}_{\mathrm{N}}$ ratios (1.46-1.74). These basalts also show the lowest $\mathrm{Th}$ and $\mathrm{Nb}$ values within Type-II rocks, whereas other trace element contents and ratios (e.g., $\mathrm{Ce} / \mathrm{Y}, \mathrm{Zr} / \mathrm{Nb}$ ) are comparable with those of Type-II rocks (Supplementary Table S3).

Subtype-IId basalts show the highest LREE/MREE and LREE/HREE enrichment (Figure 9j). Their $(\mathrm{La} / \mathrm{Sm})_{\mathrm{N}}$ and $(\mathrm{La} / \mathrm{Yb})_{\mathrm{N}}$ ratios range from 1.51 to 1.70 and from 2.33 to 3.06, respectively (Figure 10). Slightly negative anomalies in Eu can be seen in the slightly differentiated samples (Figure 9j). These basalts also display relatively high contents of $\mathrm{Nb}$ and Th (Figure 10b) and the highest $\mathrm{Nb} / \mathrm{Y}$ and the lowest $\mathrm{Zr} / \mathrm{Nb}$ ratios within the Type-II rocks.

\section{Mineral Chemistry}

\subsection{Mineral Chemistry}

\subsubsection{Olivine}

The olivine crystals are un-zoned and show quite homogeneous composition from core to rim (Supplementary Table S4). In the cumulitic gabbro MK750 from the layered gabbros complex, the olivine crystals display $\mathrm{MgO}$ ranging from 39.4 to $41.4 \mathrm{wt} . \%$ and forsterite contents in the range of 76.1-78.2. In contrast, the olivine from the cumulitic gabbros MK32, and MK35 from the isotropic gabbros complex, shows comparatively lower MgO content (36.5-38.0 wt.\% in sample MK32; 37.9-38.7 wt.\% in sample MK35) and forsterite content (71.2\%-72.6\% in sample MK32; $73.0 \%-74.1 \%$ in sample MK35). The different contents in forsterite and $\mathrm{MgO}$ observed in gabbros from the layered and isotropic gabbro complexes likely reflect the segregation of the different olivine compositions from melts at different fractionation stages. The co-variation of olivine forsterite content against anorthite content of the coexisting plagioclase likely suggests a fractionation trend comparable with that described for MOR cumulates (Figure 11a).
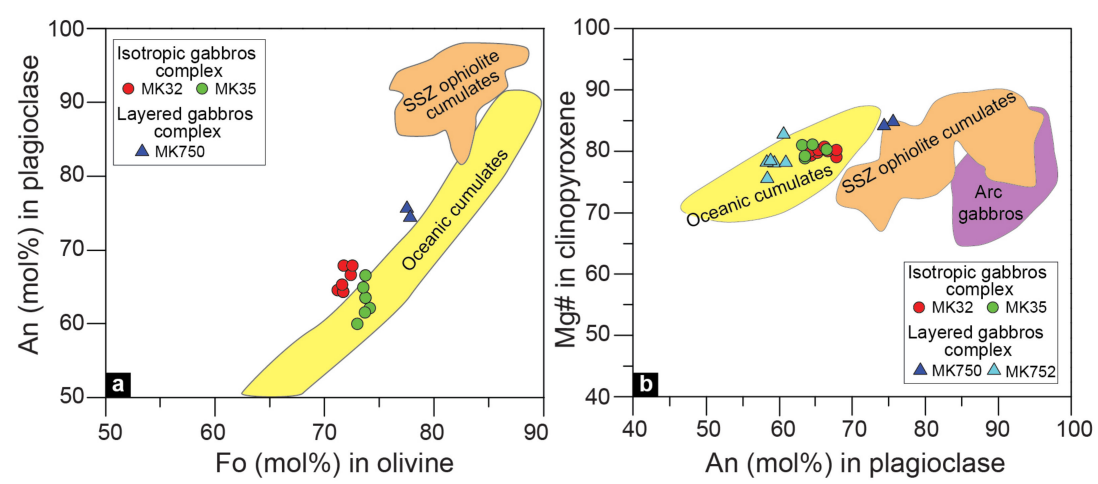

Figure 11. Forsterite (Fo) in olivine vs. Anorthite (An) in plagioclase (a) and Anorthite (An) in plagioclase vs. $\mathrm{Mg \#}$ in clinopyroxene (b) diagrams for cumulitic gabbros from the layered and isotropic gabbro of the Band-e-Zeyarat ophiolite. Field for compositional variations of supra-subduction zone ophiolites, arc gabbros, and oceanic cumulate are shown for comparisons [76-78]. 


\subsubsection{Plagioclase}

Plagioclase was analyzed in cumulitic gabbros, namely in samples MK32 and MK35 from the isotropic complex and samples MK750 and MK752 from the layered complex. In addition, this mineral was also analyzed in sample MK93 from the sheeted-dyke complex. Plagioclases from cumulitic gabbros are commonly un-zoned. They show relatively low anorthite content (58.1-75.6). However, the plagioclase crystals of each sample have quite homogeneous composition in terms of anorthite content $(\mathrm{MK} 32=64.1 \%-67.9 \%$; MK35 $=60.0 \%-66.5 \%$; MK750 $=74.4 \%-75.6 \%$; MK752 $=58.1 \%-60.9 \%$ ). Plagioclase from the sheeted-dyke complex shows anorthite contents ranging from $62.3 \%$ to $67.3 \%$ (Supplementary Table S5). In the rocks from both the layered and isotropic complex, the anorthite contents plotted against forsterite contents of the co-existing olivine overlap the compositional field for MOR-type cumulitic rocks, showing lower anorthite percentage with respect to plagioclase of cumulitic rocks from supra-subduction zone ophiolites (Figure 11a). Accordingly, the co-variation of anorthite contents in plagioclase vs. The Mg\# in co-existing clinopyroxene from the Band-e-Zeyarat cumulitic gabbros are comparable with those of MORB-type gabbros (Figure 11b). Low anorthite content is commonly related to the crystallization of plagioclase from water-poor magma, whereas high anorthite content suggests crystallization from a water-rich magma [76,79]. The low anorthite content observed in the studied plagioclases (Figure 11) suggests that they crystallized from a tholeiitic liquid at low $\mathrm{H}_{2} \mathrm{O}$ contents, as commonly observed in typical MORBs.

\subsubsection{Clinopyroxene}

Clinopyroxene was analyzed in four cumulitic gabbros (i.e., MK32, MK35, MK750, and MK752), as well as in Type-II basalts MK10 and MK105 from the volcanic sequence (Supplementary Table S6). The former sample represents a dyke crosscutting the lower part of the volcanic sequence, whereas sample MK105 corresponds to a pillow lava. The compositions of clinopyroxenes from cumulitic gabbros plot mainly in the augite field with enstatite contents ranging from $38.4 \%$ to $44.0 \%$ (Figure 12a). Most of the crystals are un-zoned (Supplementary Table S6). In fact, $\mathrm{Mg}_{2}, \mathrm{TiO}_{2}, \mathrm{Cr}_{2} \mathrm{O}_{3}$, and $\mathrm{Al}_{2} \mathrm{O}_{3}$ contents do not show significant variation from core to rim (Supplementary Table S6). $\mathrm{Mg \#}$ is generally high, ranging from 75.6 to 84.8 , and its variation in each sample is lower than $3 \%$, with the only exception being the sample MK752, in which it ranges from 75.6 to 82.8 (Supplementary Table S6).

$\mathrm{Cr}_{2} \mathrm{O}_{3}$ positively correlates with $\mathrm{Mg \#}$ value and is generally low in all samples $(0.13-0.47 \mathrm{wt} . \%)$, except for the cumulitic gabbro MK750 (0.55-0.78 wt.\%). $\mathrm{TiO}_{2}\left(0.33-1.20\right.$ wt.\%) and $\mathrm{Al}_{2} \mathrm{O}_{3}$ (1.98-3.93 wt.\%) contents are relatively high and negatively correlate with $\mathrm{Mg \# .} \mathrm{In} \mathrm{Figure} 11 \mathrm{~b}$, the clinopyroxene from the Band-e-Zeyarat ophiolite overlap the compositional field for clinopyroxene and plagioclase from MOR-gabbros from modern settings $[76,77,80]$. The clinopyroxene from basalts show augitic composition with enstatite contents in the range $36.1-49.7 \%$ (Figure 12a). They display $\mathrm{Mg \#} \mathrm{ranging} \mathrm{from} 64.6$ to 81.4 in the basaltic dyke MK10 and from 70.4 to 84.1 in the pillow basalt MK105. $\mathrm{TiO}_{2}(0.57-1.93 \mathrm{wt} . \%)$ and $\mathrm{Al}_{2} \mathrm{O}_{3}(1.71-4.65 \mathrm{wt} . \%)$ are relatively high and negatively correlate with $\mathrm{Mg \#}$. In contrast, $\mathrm{Cr}_{2} \mathrm{O}_{3}$ contents (0.01-0.98 wt.\%) show positive correlation with Mg\#. Some clinopyroxenes in basalts are weakly zoned, showing both normal and reverse zoning (Supplementary Table S6). In detail, the normal-zoned crystals show a decrease of $\mathrm{Mg} \#$ and $\mathrm{Cr}_{2} \mathrm{O}_{3}$ contents and an increase of $\mathrm{TiO}_{2}$ contents from core to rim. By contrast, the reverse-zoned crystals have core characterized by higher $\mathrm{TiO}_{2}$ contents and lower $\mathrm{Mg} \#$ and $\mathrm{Cr}_{2} \mathrm{O}_{3}$ contents with respect to the crystals rim (Supplementary Table S6). The amount of $\mathrm{TiO}_{2}$ in clinopyroxene is related to the Ti activity in the parental melt, as well as the degree of depletion of the mantle source [72]. 

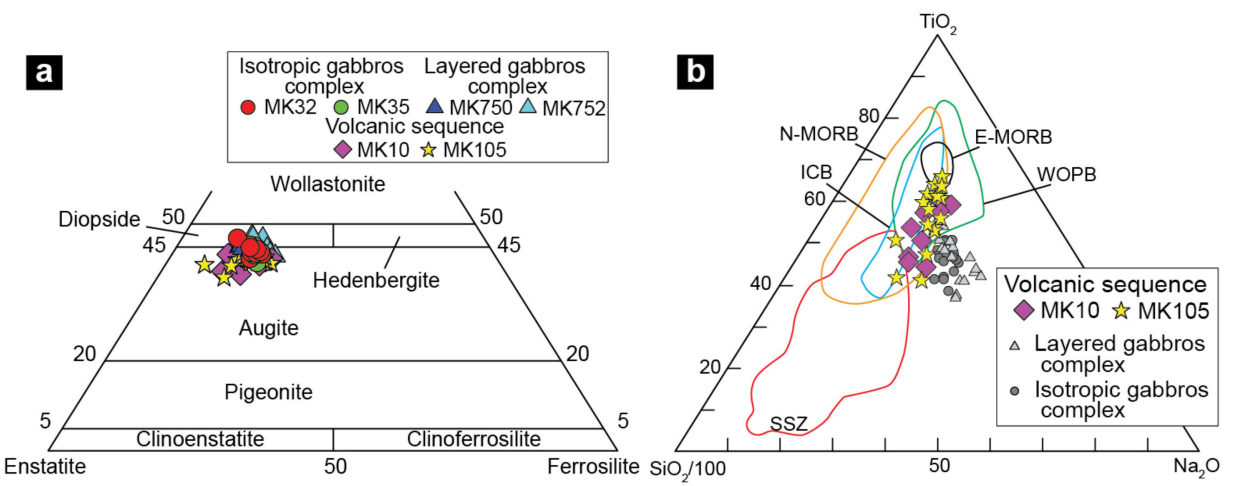

Figure 12. (a) Pyroxene quadrilateral diagram [81], and $\mathrm{TiO}_{2}-\mathrm{Na}_{2} \mathrm{O}-\mathrm{SiO}_{2} / 100$ diagram for discriminating clinopyroxenes in basalts from different oceanic settings [82] (b). Clinopyroxene from the intrusive complex of Band-e-Zeyarat ophiolite are also plotted for comparison in (b). Abbreviations, E-MORB: enriched mid-ocean ridge basalt; N-MORB: normal mid-ocean ridge basalt; WOPB: within oceanic plate basalts; ICB: Iceland basalts; SSZ: supra-subduction zone basalts.

The relatively high $\mathrm{TiO}_{2}$ contents in clinopyroxenes from the Band-e-Zeyarat ophiolite suggest their crystallization from primary magmas generated from mantle sources that did not experience significant previous partial melting events, as those commonly observed in mid-ocean ridge settings $[5,9,75]$. This is also suggested by the discrimination diagram shown in Figure 12b, in which the clinopyroxenes from basalts plot in the field for MOR setting, showing clearly distinct compositions from those of supra-subduction zone setting.

\section{Zircon U-Pb Dating}

Zircon grains from the quartz-diorite MK748 are generally euhedral and small $(<100 \mu \mathrm{m})$ with low aspect ratios. They are characterized by broad banding and oscillatory zoning. Inclusions of apatite are common. Thirteen $\mathrm{U}-\mathrm{Pb}$ analyses on thirteen zircon grains were performed on this sample. Ten datapoints yield a concordance better than $92 \%$ (Figure 13), with a weighted average ${ }^{206} \mathrm{~Pb} /{ }^{238} \mathrm{U}$ age of $125 \pm 6 \mathrm{Ma}$. Similarly, zircon grains from the quartz-dioritic sample MK749 are generally euhedral and small $(<100 \mu \mathrm{m})$ with low aspect ratios. They are characterized by darker core surrounded by brighter rims locally showing oscillatory zoning. Fourteen datapoints yield a concordance better than $92 \%$ (Figure 13) with a weighted average ${ }^{206} \mathrm{~Pb} /{ }^{238} \mathrm{U}$ age of $122 \pm 2 \mathrm{Ma}$.

Zircon grains from the plagiogranite MK422 are generally euhedral and small $(<75 \mu \mathrm{m})$ with low aspect ratios. They are characterized by sector and oscillatory zoning. Euhedral grains without apparent zoning also occur. Inclusions of apatite are common. Fifteen U-Pb analyses on fifteen zircon grains were collected for the MK422 sample. All data resulted severely discordant with only four sub-concordant data without a significant cluster (Figure 13). Zircon grains from the plagiogranite MK423 are generally euhedral and small $(<75 \mu \mathrm{m})$ with low aspect ratios. They are characterized by oscillatory zoning. Sixteen $\mathrm{U}-\mathrm{Pb}$ analyses were performed on sixteen grains. Some of the U-Pb data resulted discordant. Nonetheless, eight concordant and sub-concordant (concordance better than 92\%) data provided a weighted average ${ }^{206} \mathrm{~Pb} / 238 \mathrm{U}$ age of $129 \pm 2 \mathrm{Ma}$ (Figure 13). 

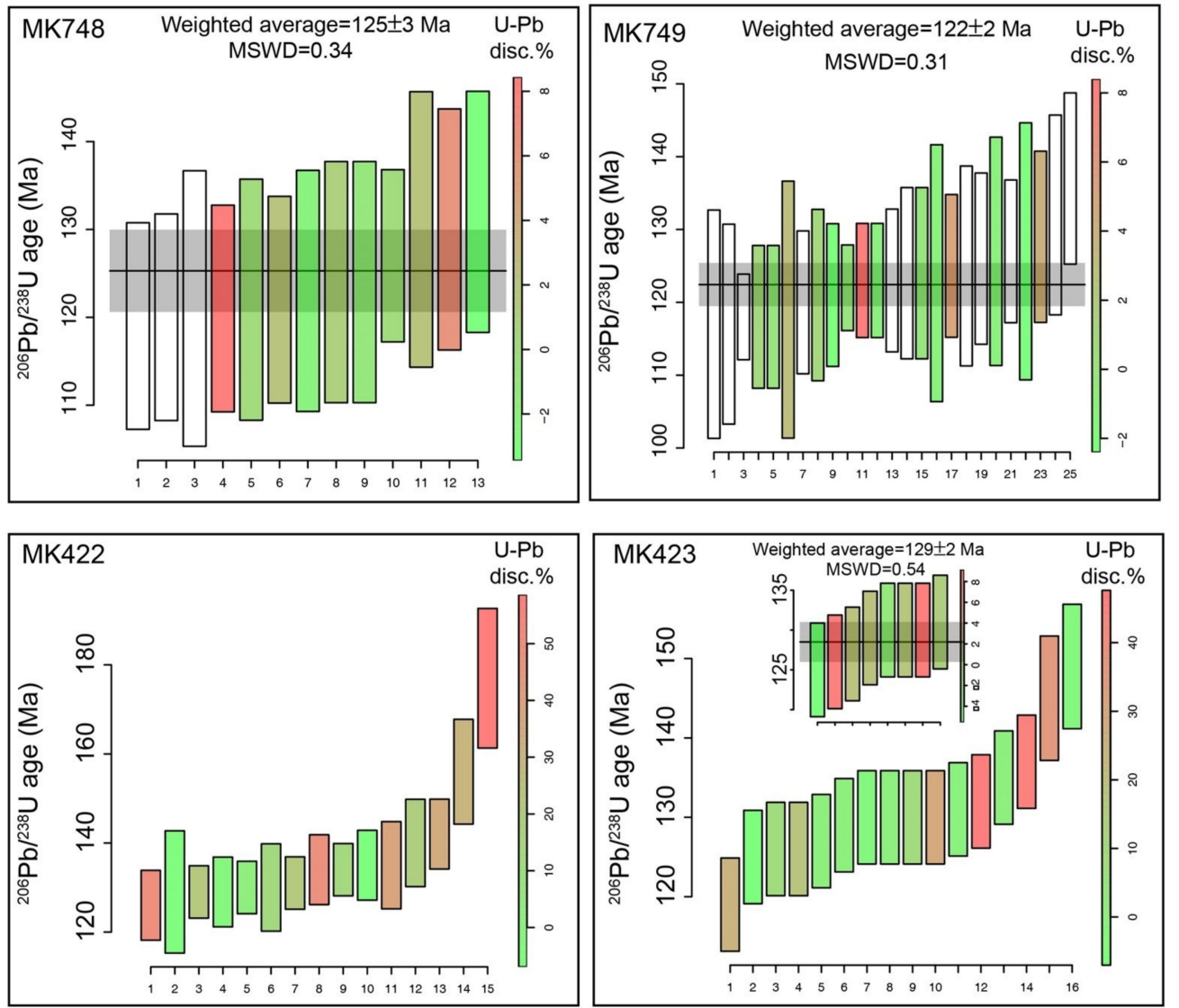

Figure 13. ${ }^{206} \mathrm{~Pb} /{ }^{238} \mathrm{U}$ age distribution of concordant and sub-concordant (discordance $< \pm 8 \%$ ) data and discordant data (unfilled bars). The weighted average age and the relative Mean Square Weighted Deviates (MSWD) are also reported and refer only to filled bars.

\section{Discussion}

\subsection{Melt Petrogenesis}

Our petrogenetic discussion will be focused on the identification of the possible mantle sources and their melting conditions (e.g., degree of partial melting and melting depth), with the aim of better constraining the tectono-magmatic setting of formation of the Band-e-Zeyarat ophiolite. Incompatible elements and REE composition of basaltic rocks is thought to be largely dependent on the composition of the mantle source and its degree of partial melting, rather than fractional crystallization processes [72]. In addition, even in the presence of moderate amounts of fractional crystallization of mainly olivine + plagioclase + clinopyroxene, ratios of incompatible elements (e.g., $\mathrm{Zr} / \mathrm{Nb}, \mathrm{Nb} / \mathrm{Y}$, $\mathrm{Th} / \mathrm{Ta}, \mathrm{Th} / \mathrm{Tb}$, and REE) in magmatic rocks are assumed to represent those of the associated mantle source [83]. For these reasons, the following petrogenetic discussion will be based on the relatively less fractionated basalts for each geochemical type. Our data show that the magmatic rocks from the Band-e-Zeyarat ophiolite basically include two geochemical types: Type-I showing N-MORB affinity and Type-II showing E-MORB affinity. According to their chemical features, Type-I and Type-II rocks were likely originated from partial melting of chemically different mantle sources. Information about the possible mantle sources can be obtained using ratios of hygromagmatophile element ratios, such as $\mathrm{Th} / \mathrm{Ta}$ and $\mathrm{Th} / \mathrm{Tb}$ ratios.

In fact, $\mathrm{Th}, \mathrm{Ta}$, and $\mathrm{Tb}$ are weakly fractionated during either fractional crystallization or partial melting and, therefore, their ratios in the basaltic rocks are mainly controlled by the elemental ratios of the mantle source $[83,84]$. A first discrimination of the possible mantle sources associated with the different Type-I and Type-II rocks can be obtained from Figure 14a, which shows that Type-I 
basalts have $(\mathrm{Th} / \mathrm{Tb}) /(\mathrm{Th} / \mathrm{Ta})$ ratios overlapping those of N-MORBs, whereas Type-II basalts show ratios similar to those of E-MORBs. Accordingly, Figure 14b shows that Type-I primary basalts plot close to the composition of the typical N-MORB [85], suggesting that they were generated from a depleted MORB-type sub-oceanic mantle source. In contrast, Type-II basalts plot along the N-MORB-OIB mixing line, suggesting that these rocks are generally compatible with a genesis from depleted MORB-type mantle, which was metasomatized by OIB-type (plume-type) chemical components. Further information on petrogenesis of the studied rocks can be derived from the $\mathrm{Nb} / \mathrm{Yb}-\mathrm{TiO}_{2} / \mathrm{Yb}$ co-variation (Figure 14c). This diagram highlights the depth of melting and mantle source composition (i.e., depletion vs. enrichment), as the variance of $\mathrm{TiO}_{2} / \mathrm{Yb}$ values is almost entirely dependent on garnet residues during melting, whereas the $\mathrm{Nb} / \mathrm{Yb}$ variation mainly depends on source composition and melting degree [10]. In fact, on the $\mathrm{TiO}_{2} / \mathrm{Yb}-\mathrm{Nb} / \mathrm{Yb}$ diagram (Figure 14c), Type-I and Subtype-IIa relatively primitive basalts plot in the MORB array, suggesting that they originated from partial melting at relatively shallow depths (i.e., spinel-facies mantle). In contrast, Subtypes-IIb, IIc, and IId basalts have higher $\mathrm{TiO}_{2} / \mathrm{Yb}$ ratios than MORB, suggesting deeper melting with involvement of a garnet-bearing mantle source (Figure $14 \mathrm{c}$ ). The $\mathrm{Nb} / \mathrm{Yb}$ ratios further suggest that Type-I basalts were generated from a depleted N-MORB-type mantle source without any influence of plume-type chemical components, whereas Type-II basalts show $\mathrm{Nb} / \mathrm{Yb}$ ratios higher than Type-I rocks, as well as a co-variation of $\mathrm{TiO}_{2} / \mathrm{Yb}$ and $\mathrm{Nb} / \mathrm{Yb}$ ratios, which indicates plume-ridge interaction (Figure 14c).

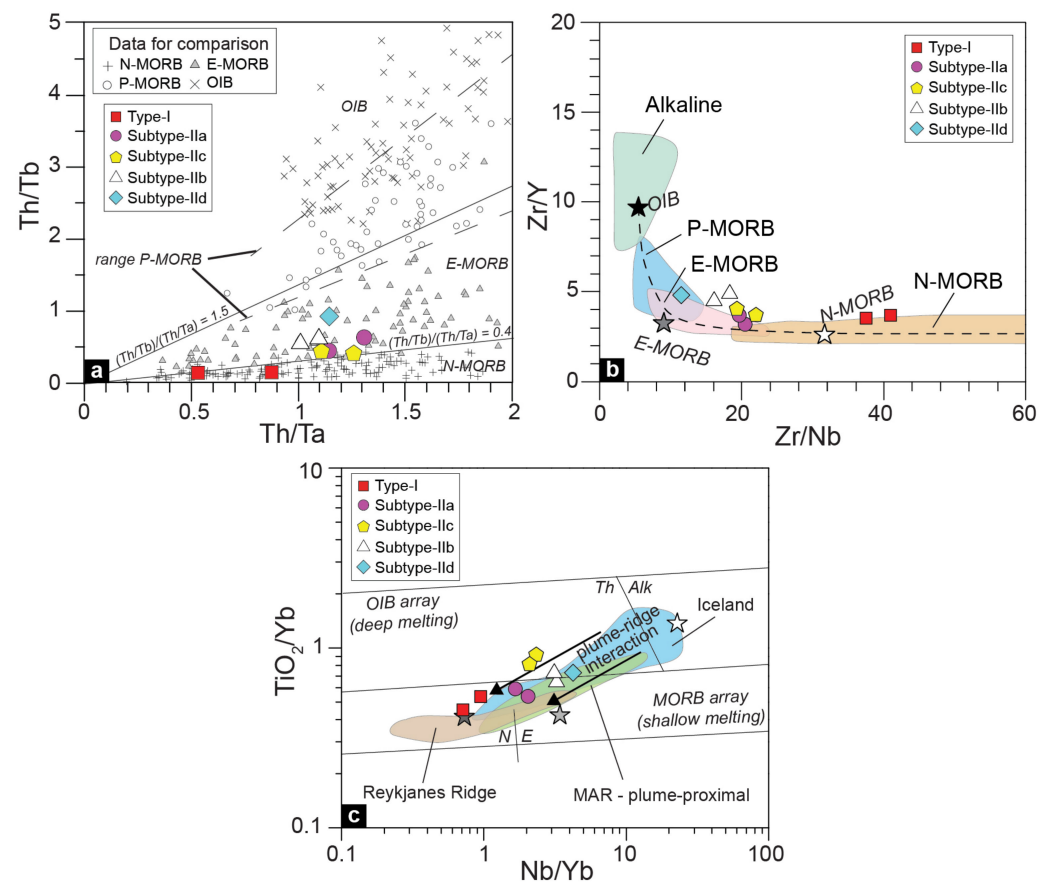

Figure 14. Diagrams showing the co-variation of some trace element ratios for subvolcanic and volcanic rocks from the sheeted dyke complex and volcanic sequence of the Band-e-Zeyarat ophiolite. (a) $\mathrm{Th} / \mathrm{Tb}$ vs. Th/Ta diagram for primitive basalts for each geochemical type and subtype. Compositions of oceanic subduction-unrelated rocks are shown for comparison [9,86-88]. (b) $\mathrm{Zr} / \mathrm{Nb} \mathrm{vs}$. $\mathrm{Zr} / \mathrm{Y}$ diagram for primitive basalts for each geochemical type and subtype. N-MORB, E-MORB, and OIB end-members are from Sun and McDonough [73]. Fields indicate compositional variation for different types of basalts from subduction-unrelated ophiolites and modern oceanic setting. Data source [85-93]. The dashed line represents the mixing curve calculated using OIB and N-MORB end-members (from Le Roex et al. [89]). (c) $\mathrm{Nb} / \mathrm{Yb}$ vs. $\mathrm{TiO}_{2} / \mathrm{Yb}$ diagram from Pearce [10] for primitive basalts for each geochemical type. Compositional fields for basalts erupted in modern plume-ridge interaction are shown for comparison [10]. Composition of typical N-MORB (dark grey star), E-MORB (light grey star), and OIB (white star) are from Sun and McDonough [73]. 
Given this evidence, we performed non-modal, batch partial melting modeling using both $\mathrm{Nb} / \mathrm{Yb}$-Th co-variation as well as REE composition (Figures 15 and 16). Plots of $\mathrm{Th}$ vs. $\mathrm{Nb} / \mathrm{Yb}$ are particularly useful for distinguishing between melting in the spinel and garnet stability fields [94], whereas the abundance of $\mathrm{Th}$ and $\mathrm{Nb}$ is particularly useful for evaluating the enrichment of the source $[9,95]$. In this model, two compositionally different mantle sources are considered based on the diagrams in Figure 14: (1) a depleted MORB mantle (DMM) source [96] melting in the spinel-facies, and (2) a theoretical DMM source enriched in LREE and incompatible elements by a plume-type chemical component (i.e., plume-influenced source of Saccani [9] or plume-proximal ridge of Pearce [10]) that melts either in the spinel- or garnet-facies mantle (source S2 in Figures 15 and 16). It should however be noted that the composition of the enriched source S2 cannot be precisely constrained. In our model, we calculated the theoretical composition of the enriched source S2 starting from a DMM slightly metasomatized and enriched in LREE, $\mathrm{Th}$, and $\mathrm{Nb}$ by the OIB-type chemical component. An enriched mantle source typical for alkaline basalts [97] was used for representing the OIB-type chemical component (Figure 16b-d). This assumption agrees with petrogenetic studies on E-MORB basalts from both modern oceanic setting and ophiolites, which are interpreted as possibly derived from a DMM source that was metasomatized to varying degrees by an OIB-type component $[85,89-94,98,99]$. The composition in terms of REE, Th, and $\mathrm{Nb}$ of the DMM source, the OIB-type mantle source, and the theoretical enriched mantle source S2, as well as their modal compositions and melting proportions [93], and partition coefficients [93,100-106] used in the models in Figures 15 and 16, are given in Supplementary Table S8.

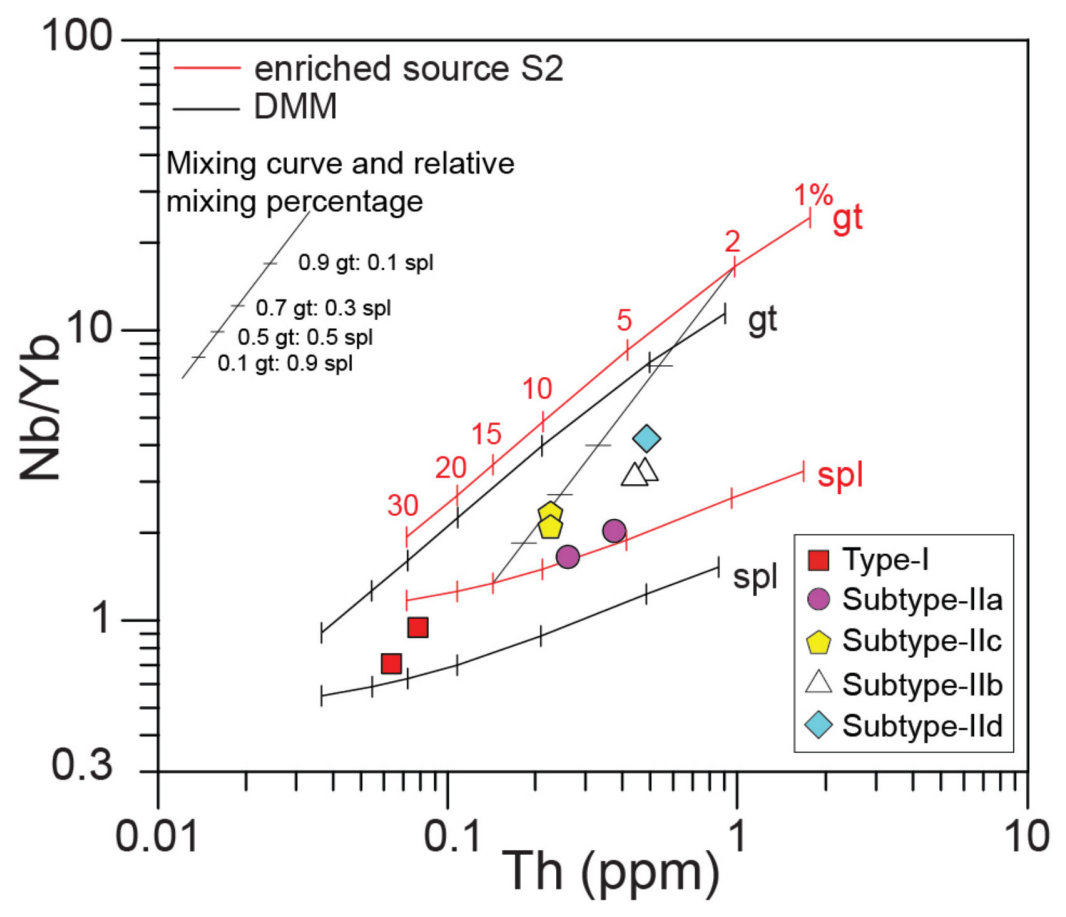

Figure 15. Melt curve models based on $\mathrm{Th} \mathrm{vs} . \mathrm{Nb} / \mathrm{Yb}$ and compositions of the relatively more primitive basalts for each rock type and subtype. Melt curves are calculated using non-modal, batch partial melting of DMM [96] and a theoretically enriched mantle source (S2). Ticks on all melting curves indicate the same percentages of partial melting as shown for the melting curve of source S2 in the garnet-facies. The thin black line represents the mixing line of various melt fractions from garnet- and spinel-facies mantle. Input parameters for the REE models (source modes, melting proportions, and partition coefficients), as well as compositions of the mantle sources, are shown in Supplementary Table S8. 


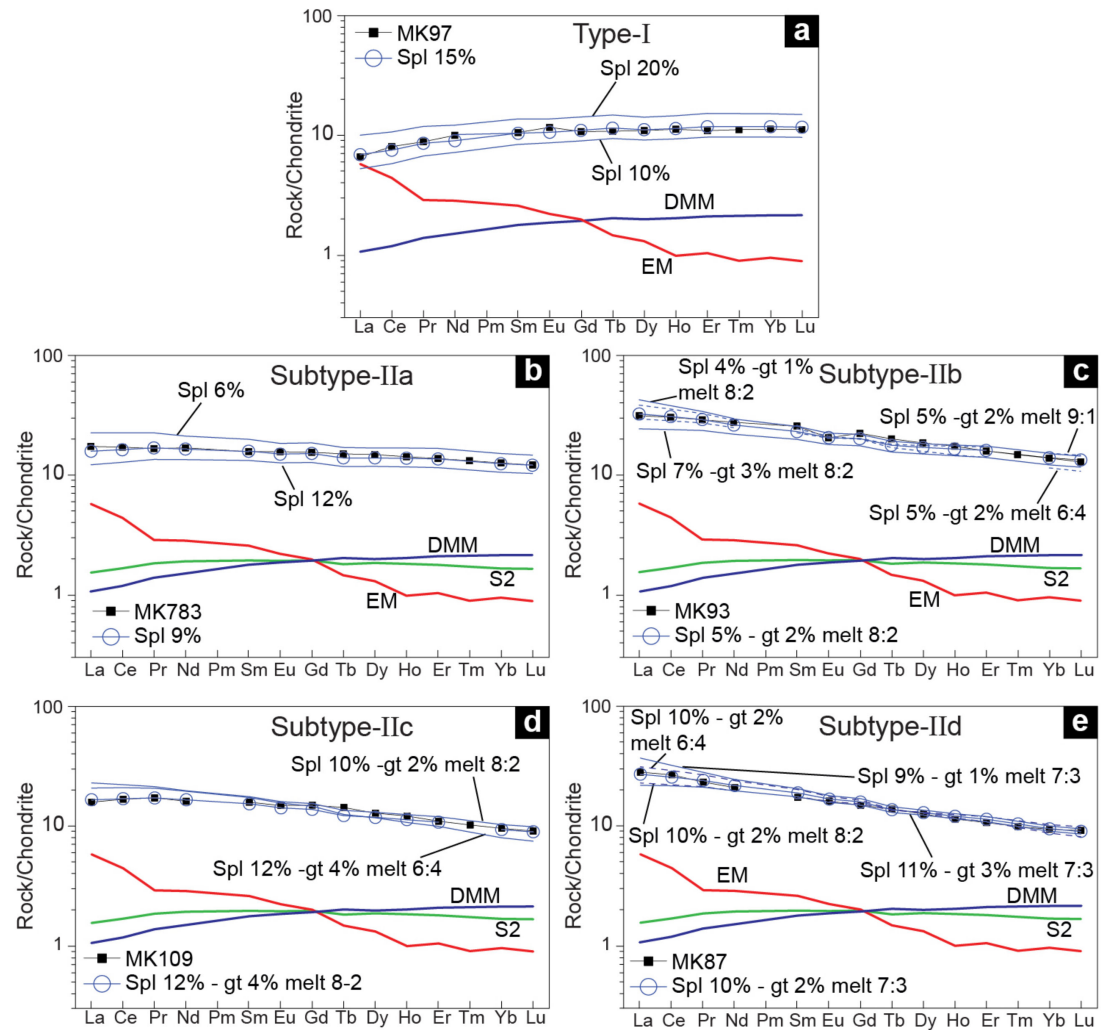

Figure 16. Calculated chondrite-normalized [73] rare earth element (REE) liquid composition for parental melts derived from different mantle sources, assuming various degrees of non-modal batch partial melting: (a) Type-I; (b) Type-IIa; (c) Type-IIb; (d) Type-IId; (e) Type-IIe. Abbreviations: EM: enriched mantle source (from Lustrino et al. [89]); DMM: depleted MORB mantle [82]; S2: enriched mantle source S2. Input parameters for the REE models (source modes, melting proportions, and partition coefficients), as well as compositions of the different mantle sources, are shown in Supplementary Table S8.

\subsubsection{Type-I}

Depletion of LREE with respect to MREE and HREE (Figure $9 \mathrm{~b}$ ) and low $\mathrm{Nb} / \mathrm{Yb}$ and $\mathrm{TiO}_{2} / \mathrm{Yb}$ ratios (Figure 14c) displayed by Type-I rocks suggest a melt generation from a depleted, sub-oceanic mantle source (DMM) in the spinel stability field. The model in Figure 15 shows, indeed, that the Th- $\mathrm{Nb}-\mathrm{Yb}$ composition of Type-I primitive basalts can be explained by $15 \%-18 \%$ of partial melting of a DMM source [96] in the spinel-facies. The REE modeling (Figure 16a) fully confirms the results obtained from the Th vs. $\mathrm{Nb} / \mathrm{Yb}$ model. In fact, the REE composition of the relatively primitive basalt MK97 fits well with the liquid composition calculated for 15\% of partial melting of a DMM source in the spinel-facies (Figure 16a).

\subsubsection{Subtype-IIa}

The Subtype-IIa rocks have clear E-MORB geochemical affinity with different extents of LREE/HREE enrichment (Figures $9 \mathrm{~g}$ and 10a), as well as low $\mathrm{TiO}_{2} / \mathrm{Yb}$ ratios (Figure 14c), which suggest a melting of an enriched sub-oceanic mantle source in the spinel stability field. The chemical features of Subtype-IIa basalts cannot be modelled by very low degrees of partial melting of a DMM mantle source. In fact, Subtype-IIa primitive rocks clearly plot at higher values of both $\mathrm{Th}$ and $\mathrm{Nb} / \mathrm{Yb}$ with respect to the calculated melting curve for partial melting of the DMM source (Figure 15). In contrast, the $\mathrm{Th}-\mathrm{Nb} / \mathrm{Yb}$ composition of Subtype-IIa relatively primitive basalts is compatible with $6 \%-8 \%$ partial melting in the spinel-facies of the enriched mantle source S2 (Figure 15). Accordingly, results of the REE 
modeling indicate that the REE composition of Subtype-IIa primitive basalts is compatible with the $\sim 9 \%$ partial melting of the S2 source in the spinel-facies (Figure 16b). In agreement with the Th- $\mathrm{Nb}-\mathrm{Yb}$ modeling, higher and lower degrees of partial melting fail to reproduce the REE composition of the primitive basalts of the Type-IIa. Likewise, very low degrees $(<3 \%)$ of partial melting of a DMM source cannot reproduce the REE patterns of Subtype-IIa basalts (not shown).

\subsubsection{Subtype-IIlb}

Subtype-IIb rocks show higher LREE/HREE enrichment (Figure 9g,h and Figure 10a) and $\mathrm{TiO}_{2} / \mathrm{Yb}$ ratios (Figure 14c) compared to Subtype-IIa rocks. These features, particularly the $\mathrm{TiO}_{2} / \mathrm{Yb}$ ratios, suggest an involvement of residual garnet during partial melting. In fact, the model in Figure 15 shows that $\mathrm{Th}-\mathrm{Nb}$ - $\mathrm{Yb}$ composition of Subtype-Ilb relatively primitive basalts cannot be explained by partial melting in the spinel-facies alone. Rather, the composition of these basalts can be explained by 2\% partial melting of mantle source S2 in the garnet-facies and $\sim 4 \%$ partial melting of the same source in the spinel facies. Accordingly, the REE composition of these basalts is compatible with partial melting of the mantle source S2 that starts to melt at low degrees $(\sim 2 \%)$ in the garnet-facies and continues to melt to larger extents $(\sim 5 \%)$ in the spinel-facies (Figure 16c). The mixing proportion between melts generated at spinel- and garnet-facies that best fits the REE composition of the primitive basalt MK93 is 8:2 (Figure 16c). In Figure 16c, it is also shown that calculations involving different degrees of partial melting in the garnet- and spinel-facies, as well as different mixing proportions of melts generated at spinel- and garnet-facies, fails to reproduce the REE composition of Subtype-IIb basalts.

\subsubsection{Subtype-IIc}

Subtype-IIc rocks show a general LREE/HREE enrichment, which is comparable to that of Subtype-IIa basalts but shows the lowest LREE/MREE and MREE/HREE enrichment within Type-II rocks (Figures $9 \mathrm{i}$ and $10 \mathrm{a}$ ). Primitive basalts show relatively high $\mathrm{TiO}_{2} / \mathrm{Yb}$ ratios (Figure $14 \mathrm{c}$ ) and low HREE contents (e.g., $\left.\mathrm{Yb}_{\mathrm{N}}=9.5\right)$, which suggest an involvement of residual garnet during partial melting. Though the REE patterns of these rocks are appreciably different from those of other Type-II basalts, ratios of hygromagmatophile element ratios are comparable with those of Subtype-IIa and IIb basalts (Figure 14a), suggesting a compositionally similar mantle source. Therefore, we postulate that the different REE patterns of these rocks are most likely due to different melting conditions of the enriched source S2. In fact, the model in Figure 15 shows that the Th- $\mathrm{Nb}-\mathrm{Yb}$ composition of Subtype-IIc primitive basalts can be explained by $2 \%-4 \%$ and $10 \%-14 \%$ partial melting of the theoretical source S2 in the garnet- and spinel-facies, respectively. The REE composition of Subtype-IIc primitive basalt MK109 can be explained by mixing with proportion 8:2 of liquids generated form $4 \%$ and $12 \%$ partial melting of mantle source S2 in the garnet and spinel stability fields, respectively (Figure 16d).

\subsubsection{Subtype-IId}

Subtype-IId rocks show the highest enrichment in LREE with respect to MREE and HREE observed within the Type-II rocks (Figures $9 \mathrm{j}$ and 10a). Primitive basalts show $\mathrm{TiO}_{2} / \mathrm{Yb}$ ratios (Figure $14 \mathrm{c}$ ) and low HREE absolute contents (e.g., $\left.\mathrm{Yb}_{\mathrm{N}}=9.3\right)$, which suggest an involvement of residual garnet in the mantle source. In our model (Figure 15), the Subtype-IId primitive basalt MK87 plots very close to Subtype-IIb basalts. In fact, similar to Subtype-IIb, the Th-Nb-Yb composition of sample MK87 is compatible with $\sim 2 \%$ partial melting of the theoretical source S2 in the garnet-facies, and $\sim 7 \%-8 \%$ partial melting of S2 in the spinel-facies. Accordingly, the REE model shows that the REE composition of the relatively more primitive Subtype-IId basalt is compatible with partial melting of the mantle source S2 that melts in the garnet-facies for $2 \%$ partial melting and continues to melt in the spinel-facies for about $10 \%$ (Figure 16e). The mixing proportion between melts generated at spinel- and garnet-facies that best fits the REE composition of the primitive basalt MK87 is 7:3 (Figure 16e). It follows that the relatively high LREE/HREE and MREE/HREE ratios displayed by Subtype-IId rocks (Figure 10a) are most likely due to a slightly higher contribution of melt formed in the garnet-facies mantle with 
respect to Subtype-IIb and Subtype-IIc rocks. Nonetheless, it cannot be excluded that the relatively higher LREE enrichment displayed by Subtype-IId basalts may result from partial melting of a mantle source slightly more enriched in LREE than the theoretical source S2. The (Th/Tb)/(Th/Ta) ratios of the primitive Subtype-IId basalt are indeed slightly higher than those of other Subtype-II basalts (Figure 14a). However, the differences in $(\mathrm{Th} / \mathrm{Tb}) /(\mathrm{Th} / \mathrm{Ta}$ ) ratios in the distinct Subtype-II basalts are so small that it is difficult to unequivocally confirm this hypothesis.

\subsection{Tectono-Magmatic Setting of Formation of the Band-e-Zeyarat Ophiolite and Geodynamic Implications}

Previous studies have suggested that the rocks from the Band-e-Zeyarat ophiolite were derived from mafic melts with E-MORB composition and show an Early Cretaceous age (141-143 Ma, based on ${ }^{40} \mathrm{Ar}^{-39} \mathrm{Ar}$ methods) [24]. Our new whole rock geochemical data, geochronological data, as well as the mineral chemistry data, are in agreement with this conclusion. In fact, they highlight that the oceanic basin in which the Band-e-Zeyarat ophiolite was formed (i.e., the North Makran Ocean), was characterized by an Early Cretaceous, chemical composite upper oceanic crust, consisting of $\mathrm{N}-\mathrm{MORBs}$ and different varieties of E-MORBs. The petrological evidence presented in Section 9.1 clearly indicates that the Band-e-Zeyarat ophiolite was generated in a mid-ocean ridge setting from partial melting of mantle sources, showing a combination of distinct compositions and different partial melting degrees and melting depths. The absolute ages of 122-129 Ma obtained in this work combined with previously published ages of 141-143 Ma [24] suggest that a spreading ridge characterized by enriched-type mantle sources was active in the North Makran Ocean from the lowermost Early Cretaceous.

In Figure 17, we present a schematic tectono-magmatic model that can explain the formation of the Band-e-Zeyarat composite upper crustal sequence. Type-I (N-MORB) rocks were generated from the partial melting in the spinel-facies of a depleted sub-oceanic asthenosphere without influences of OIB-type components (Figures 15, 16a and 17). Type-II (E-MORB) rocks were derived from the partial melting of a comparatively more enriched mantle source (S2 source), which corresponds to an asthenospheric depleted sub-oceanic mantle bearing OIB-type chemical components (Figures 15, 16b-e and 17). We have shown in the petrogenetic discussion (Figures 15c and 16b-e) that the different Subtype-II rocks are compatible with different melting conditions in terms of partial melting degree and depth of melting of the enriched mantle source S2.

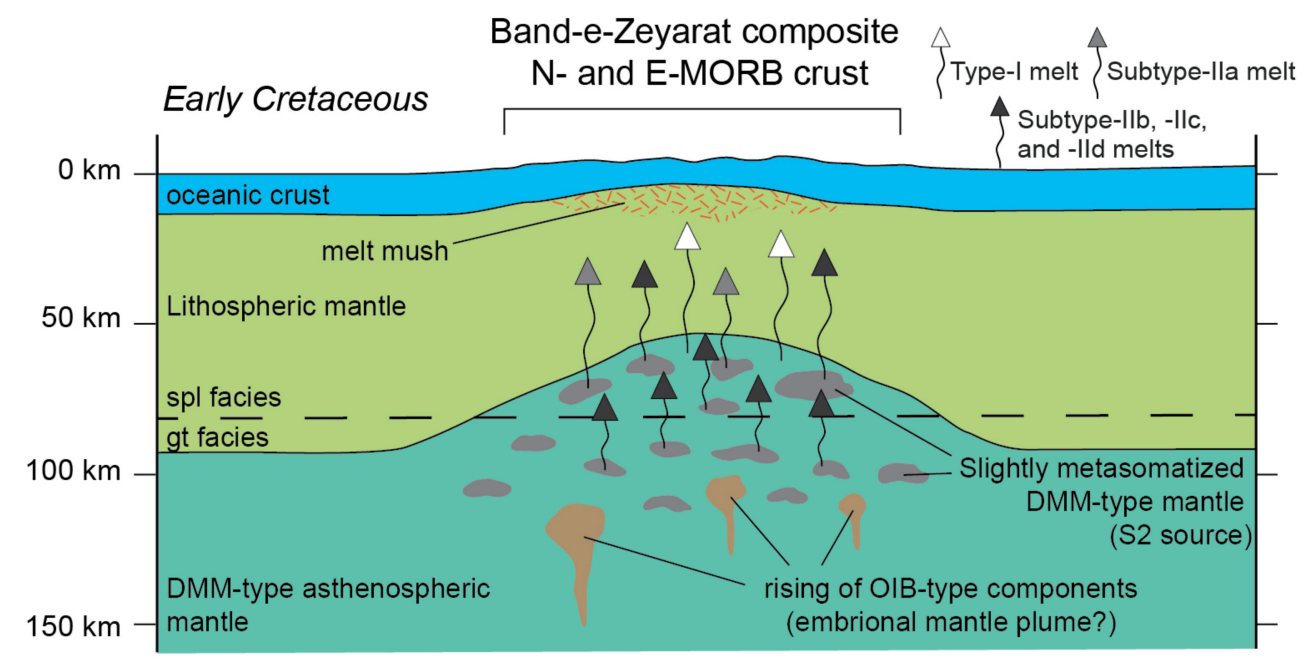

Figure 17. Conceptual two-dimensional cartoon showing the petrogenetic processes responsible for the formation of the $\mathrm{N}$ - and E-MORB composite crust of the Band-e-Zeyarat ophiolite in a mid-oceanic ridge tectono-magmatic setting. Abbreviations: N-MORB: normal mid-oceanic ridge basalt; E-MORB: enriched mid-oceanic ridge basalt; OIB: oceanic island basalt; DMM: depleted MORB mantle. 
The tectono-magmatic setting shown in Figure 17 can explain the formation of these slightly different E-MORBs forming the Band-e-Zeyarat ophiolite. We propose that Type-IIa melts were generated from the partial melting of the enriched mantle source S2 in the spinel-facies. By contrast, the Type-IIb, IIc, and IId rocks may have been generated from variable degrees of partial melting of the same S2 source, which started to melt in the garnet-facies and continued to melt in the spinel-facies (Figure 17). The tectono-magmatic model proposed in Figure 17 is compatible with two different mid-ocean ridge settings: (1) a mid-ocean ridge proximal to a mantle plume that was active during the formation of the Band-e-Zeyarat ophiolite, and (2) a mid-ocean ridge associated with a heterogeneous sub-oceanic asthenospheric mantle bearing inherited portions enriched by ancient mantle plume activity. The discriminations between these two distinct tectono-magmatic settings based only on petrogenetic data from the Band-e-Zeyarat ophiolites is difficult to be made. To this purpose, some useful constraints can be obtained from the comparison with the tectono-magmatic events occurring in the Makran area and, more generally, in the Middle East-Tibet area during Cretaceous times. The Band-e-Zeyarat ophiolite, together with the Fannuj-Maskutan and Remesk-Moktarabad ophiolites, has been interpreted as an Early Cretaceous ophiolite, which represents the remnants of the North Makran Ocean $[15,17]$. Recent works on the eastern ophiolites of the North Makran domain have shown that the Fannuj-Maskutan ophiolites (Figure 1c) consist of island arc tholeiitic gabbros and E-MORB basalts. These ophiolites are interpreted as formed in a supra-subduction zone basin (back-arc basin) located between the Lut Block and the Bajgan-Durkan microcontinent during the Late Jurassic-Early Cretaceous [19]. On the other hand, recent data from the Ganj Complex in the western North Makran indicate that the subduction-related magmatism in the western North Makran is Late Cretaceous in age [23] and, therefore, it is much younger than the Early Cretaceous $\mathrm{N}$ - to E-MORB magmatism recorded by the Band-e-Zeyarat ophiolite. This evidence allowed us to exclude that the Band-e-Zeyarat ophiolite were formed in the same Late Jurassic-Early Cretaceous supra-subduction zone tectonic setting of formation of the eastern North Makran ophiolites. Recent works have documented the widespread occurrence of Late Cretaceous alkaline and oceanic plateau basalts, as well as P-MORB in the Makran area, namely in the Colored Mélange and in the Durkan Complex. The genesis of these rocks has been related either to oceanic within-plate mantle plume magmatism [22,107] or to a plume-ridge interaction [26]. In any case, these data point out that during the Late Cretaceous, a mantle plume activity strongly influenced the magmatic history of the Northern Makran Ocean. Accordingly, mantle plume activity has been documented in the Early Cretaceous at a regional scale from the Caucasus to Tibet $[108,109]$.

Given this regional evidence, we suggest that the N-MORB-E-MORB association in the Band-e-Zeyarat ophiolite can most likely be related to a mantle plume activity rather than an inherited metasomatized asthenospheric mantle. However, an active mantle plume close to a MOR setting commonly results in abundant eruptions of E-MORB, P-MORB, and alkaline basalts formed through polybaric melting, as well as a time-dependent magmatic evolution from depleted N-MORB to enriched E-MORB, P-MORB, and alkaline basalts $[10,95,109]$. By contrast, in the case of melting of a sub-oceanic mantle showing inherited OIB-type metasomatism, the volume of E-MORB, P-MORB, and alkaline basalts is commonly subordinate with respect to N-MORB and partial melting is by far limited to the spinel-facies mantle, as observed in modern oceanic settings [110], as well as in many ophiolitic settings $[5,9,10,85,94,99,111]$. In the Band-e-Zeyarat ophiolites, the E-MORB rocks are volumetrically largely prevailing compared to N-MORBs. In addition, we can observe, as a general tendency, the increase of the abundance of E-MORBs toward the top of the sequence. Therefore, we postulate that the Band-e-Zeyarat ophiolite most likely represents an excellent fossil example of a plume-proximal mid-oceanic ridge, which recorded a plume-ridge interaction during an embryonic stage of a mantle plume activity in the Early Cretaceous. In our model, this plume activity was characterized by the rising of OIB-type chemical components from a deep and enriched mantle source, which metasomatized the existing asthenospheric sub-oceanic mantle (Figure 17). Recent works in the Makran area $[22,53,107]$ demonstrated the occurrence of E-MORBs, P-MORBs, and alkaline OIBs 
formed in seamounts and oceanic plateau settings associated with Late Cretaceous mantle plume activity. The new evidence of Early Cretaceous plume-ridge interaction in the Band-e-Zeyarat ophiolite is, therefore, highly significant as they represent, up to now, the earliest witness of mantle plume activity in the Makran sector of the Neo-Tethys. This conclusion fits well and improves the extant literature data from Makran [22,53,102] and neighboring collisional belts [90,95,108,109], which point out a plume activity starting in the Early Cretaceous and continuing in the Late Cretaceous in the Neo-Tethys realm. This data agrees well with the evidence for two major pulses of mantle plume activities at a worldwide scale during the Early and Late Cretaceous (i.e., from 122 to $70 \mathrm{Ma}$, see Reference [27]); in fact, examples of oceanic plateau and continental flood basalts associated with Cretaceous mantle plume are well-known in the Indian Ocean (e.g., Kerguelen Plateau [28]), in the Pacific Ocean (e.g., Ontong Java Plateau [29,30]; Hikurangi Plateau [31]), and in the Caribbean region (Caribbean Plateau [29]). Our new findings suggest that the worldwide Cretaceous plume activity also affected the Makran sector of the Neo-Tethys. Therefore, the Band-e-Zeyarat ophiolites may represent a potential natural laboratory to unveil the processes responsible for crustal growth during plume activities at a global scale.

\section{Conclusions}

1. The Band-e-Zeyarat ophiolite consists of (from bottom to top): ultramafic cumulates, layered gabbros, isotropic gabbros, as well as a sheeted dyke complex and a volcanic series including mainly basalts and minor andesites and rhyolites.

2. Whole rock chemical compositions of basaltic rocks show both N-MORB and E-MORB affinities.

3. The compositions of rock-forming minerals (i.e., olivine, plagioclase, and clinopyroxene) also point out a general MORB-type affinity of both gabbros and basalts.

4. LA-ICP-MS zircon U-Pb dating showed the age of the Band-e-Zeyarat gabbros at $122-129 \mathrm{Ma}$.

5. Band-e-Zeyarat N-MORBs formed from partial melting of a depleted sub-oceanic mantle peridotite in the spinel-facies.

6. Band-e-Zeyarat E-MORBs formed from partial melting of a depleted sub-oceanic mantle peridotite that was metasomatized by OIB-type (plume-type) components. They show different LREE, Th, $\mathrm{Nb}, \mathrm{TiO}_{2}$, and Ta contents, which point out different partial melting conditions, in terms of partial melting degrees and melting depths.

7. We suggest that the Band-e-Zeyarat ophiolite represents a chemical composite upper oceanic crust, which records an Early Cretaceous plume-ridge interaction in the Makran Neo-Tethys.

8. The plume activity that affected the Makran sector of the Neo-Tethys can be framed into the plume activities observed worldwide during the Cretaceous.

Supplementary Materials: The following are available online at http://www.mdpi.com/2075-163X/10/12/1100/s1, Table S1: Analyzed elements, accuracy and detection limits for X-Ray Fluorescence Spectrometry and Inductively Coupled Plasma-Mass Spectrometry, Table S2: Whole rock major (wt.\%) and trace (ppm) element composition of magmatic rocks from the intrusive complex, Table S3: Whole rock major (wt.\%) and trace (ppm) element composition of subvolcanic and volcanic rocks from the sheeted dyke complex and volcanic sequence, Table S4: Mineral chemistry of olivines from intrusive rocks, Table S5: Mineral chemistry of plagioclases from intrusive and subvolcanic rocks, Table S6: Mineral chemistry of clinopyroxenes from intrusive, subvolcanic, and volcanic rocks, Table S7: Zircon U-Pb isotopic ratios and ages, Table S8: Input parameters for the partial melting models used for the different volcanic and subvolcanic rock-types, Figure S1: Cathodoluminescence images for zircons.

Author Contributions: E.B. did the geological study, collected samples, performed whole rock and mineral chemistry analytical studies, interpreted the data, prepared tables and figures, and wrote the manuscript; M.D. did the geological study, collected samples, and wrote the manuscript; A.D. did the geological study, collected samples, and wrote the manuscript; L.V. collected samples and did zircons separation; A.L. did the geochronological analyses; M.M. did the geological study and wrote the manuscript; L.P. did the geological study, collected samples, and wrote the manuscript; F.Z. did the mineral chemistry analyses and interpreted the data; E.S. interpreted whole rock chemical data, prepared tables and figures, wrote the manuscript, and supervised the research. All authors have read and agreed to the published version of the manuscript. 
Funding: The study was carried out on assignments from different institutions. Darius Project (Head M.M.); University of Pisa, Italy (PRA project); IGG-CNR (Pisa, Italy); University of Ferrara, Italy: FAR-2019 project and IUSS Mobility Research Programme (grant Mobility for Long Period to E.B.).

Acknowledgments: Thoughtful comments by three anonymous reviewers on this manuscript are gratefully acknowledged. We wish to thank R. Tassinari and R. Tamoni (Ferrara University) for assistance in whole rock chemical analyses and thin section preparation. The University Centre for Applied Geosciences (UCAG) is thanked for access to the E.F. Stumpfl Electron Microprobe Laboratory.

Conflicts of Interest: The authors declare no conflict of interest.

\section{References}

1. Maruyama, S.; Liou, J.G.; Terabayashi, M. Blueschists and eclogites of the world and their exhumation. Int. Geol. Rev. 1996, 38. [CrossRef]

2. Shervais, J.W. Birth, death, and resurrection: The life cycle of suprasubduction zone ophiolites. G3 Geochem. Geophys. Geosyst. 2001, 2, 45. [CrossRef]

3. Dilek, Y. Ophiolite concept and its evolution. In Ophiolite Concept and the Evolution of Geological Thought; Dilek, Y., Newcomb, S., Eds.; Geological Society of America Special Paper; Geological Society of America: Boulder, CO, USA, 2003; Volume 373, pp. 1-16.

4. Kusky, T.M.; Windley, B.F.; Safonova, I.; Wakita, K.; Wakabayashi, J.; Polat, A.; Santosh, M. Recognition of ocean plate stratigraphy in accretionary orogens through Earth history: A record of 3.8 billion years of sea floor spreading, subduction, and accretion. Gondwana Res. 2013, 24, 501-547. [CrossRef]

5. Dilek, Y.; Furnes, H. Ophiolite genesis and global tectonics: Geochemical and tectonic fingerprinting of ancient oceanic lithosphere. Geol. Soc. Am. Bull. 2011, 123, 387-411. [CrossRef]

6. Dilek, Y.; Furnes, H. Ophiolites and their origins. Elements 2014, 10, 93-100. [CrossRef]

7. Pearce, J.A. Immobile element fingerprinting of ophiolites. Elements 2014, 10, 101-108. [CrossRef]

8. Furnes, H.; de Wit, M.; Dilek, Y. Four billion years of ophiolites reveal secular trends in oceanic crust formation. Geosci. Front. 2014, 5, 571-603. [CrossRef]

9. Saccani, E. A new method of discriminating different types of post-Archean ophiolitic basalts and their tectonic significance using Th-Nb and Ce-Dy-Yb systematics. Geosci. Front. 2015, 6, 481-501. [CrossRef]

10. Pearce, J.A. Geochemical fingerprinting of oceanic basalts with applications to ophiolite classification and the search for Archean oceanic crust. Lithos 2008, 100, 14-48. [CrossRef]

11. Stöcklin, J. Structural history and tectonics of Iran; a review. AAPG Bull. 1968, 52, 1229-1258.

12. Kopp, C.; Fruehn, J.; Flueh, E.R.; Reichert, C.; Kukowski, N.; Bialas, J.; Klaeschen, D. Structure of the Makran subduction zone from wide-angle and reflection seismic data. Tectonophysics 2000, 329, 171-191. [CrossRef]

13. Burg, J.-P.; Dolati, A.; Bernoulli, D.; Smith, J. Structural style of the Makran tertiary accretionary complex in SE Iran. In Lithosphere Dynamics and Sedimentary Basins: The Arabian Plate and Analogues; Frontiers in Earth Sciences; Al Hosani, K., Roure, F., Ellison, R., Lokier, S., Eds.; Springer: Heidelberg, Germany, 2013; pp. 239-259. [CrossRef]

14. Penney, C.; Copley, A.; Oveisi, B. Subduction tractions and vertical axis rotations in the Zagros-Makran transition zone, SE Iran: The 2013 May 11 M w 6.1 Minab earthquake. Geophys. J. Int. 2015, 202, 1122-1136. [CrossRef]

15. Hunziker, D.; Burg, J.-P.; Bouilhol, P.; von Quadt, A. Jurassic rifting at the Eurasian Tethys margin: Geochemical and geochronological constraints from granitoids of North Makran, southeastern Iran. Tectonics 2015, 34, 571-593. [CrossRef]

16. Burg, J.-P. Geology of the onshore Makran accretionary wedge: Synthesis and tectonic interpretation. Earth-Sci. Rev. 2018, 185, 1210-1231. [CrossRef]

17. McCall, G.J.H.; Kidd, R.G.W. The Makran southeastern Iran: The anatomy of a convergent margin active from Cretaceous to present. In Trench-Forearc Geology: Sedimentation and Tectonics of Modern and Ancient Plate Margins; Leggett, J.K., Ed.; Geological Society of London Special Publications: London, UK, 1982; Volume 10, pp. 387-397.

18. Monsef, I.; Rahgoshay, M.; Pirouz, M.; Chiaradia, M.; Grégoire, M.; Ceuleneer, G. The Eastern Makran Ophiolite (SE Iran): Evidence for a Late Cretaceous fore-arc oceanic crust. Int. Geol. Rev. 2019, 61, 1313-1339. [CrossRef] 
19. Sepidbar, F.; Lucci, F.; Biabangard, H.; Zaki Khedr, M.; Jiantang, P. Geochemistry and tectonic significance of the Fannuj-Maskutan SSZ-type ophiolite (Inner Makran, SE Iran). Int. Geol. Rev. 2020, 1-28. [CrossRef]

20. McCall, G.J.H. A summary of the geology of the Iranian Makran. In The Tectonic and Climatic Evolution of the Arabian Sea Region; Clift, P.D., Kroon, F.D., Gaedecke, C., Craig, J., Eds.; Geological Society of London Special Publications: London, UK, 2002; Volume 195, pp. 147-204.

21. Moslempour, M.E.; Khalatbari-Jafari, M.; Ghaderi, M.; Yousefi, H.; Shahdadi, S. Petrology, geochemistry and tectonics of the extrusive sequence of Fannuj-Maskutan Ophiolite, southeastern Iran. J. Geol. Soc. India 2015, 85, 604-618. [CrossRef]

22. Saccani, E.; Delavari, M.; Dolati, A.; Marroni, M.; Pandolfi, L.; Chiari, M.; Barbero, E. New insights into the geodynamics of Neo-Tethys in the Makran area: Evidence from age and petrology of ophiolites from the Coloured Mélange Complex (SE Iran). Gondwana Res. 2018, 62, 306-327. [CrossRef]

23. Barbero, E.; Delavari, M.; Dolati, A.; Saccani, E.; Marroni, M.; Catanzariti, R.; Pandolfi, L. The Ganj Complex reinterpreted as a Late Cretaceous volcanic arc: Implications for the geodynamic evolution of the North Makran domain (southeast Iran). J. Asian Earth Sci. 2020. [CrossRef]

24. Ghazi, A.M.; Hassanipak, A.A.; Mahoney, J.J.; Duncon, R.A. Geochemical characteristics, ${ }^{40}$ Ar- ${ }^{39}$ Ar ages and original tectonic setting of the Band-e-Zeyarat/Dar Anar ophiolite, Makran accretionary Prism, S.E. Iran. Tectonophysics 2004, 193, 175-196. [CrossRef]

25. Kananian, A.; Juteau, T.; Bellon, H.; Darvishzadeh, A.; Sabzehi, M.; Whitechurch, H.; Ricou, L.-E. The ophiolite massif of Kahnuj (western Makran, southern Iran): New geological and geochronological data. Comptes Rendus Acad. Sci. Ser. IIA Earth Planet. Sci. 2001, 332, 543-552. [CrossRef]

26. Esmaeili, R.; Xiao, W.; Ebrahimi, M.; Zhang, J.; Zhang, Z.; Abd El-Rahman, Y.; Han, C.; Wan, B.; Ao, S.; Song, D.; et al. Makran ophiolitic basalts (SE Iran) record Late Cretaceous Neotethys plume-ridge interaction. Int. Geol. Rev. 2019, 1-21. [CrossRef]

27. Kerr, A.C. Oceanic Plateaus. In Treatise on Geochem; Elsevier: Amsterdam, The Netherlands, 2014; pp. 631-667. [CrossRef]

28. Coffin, M.F.; Pringle, M.S.; Duncan, R.A. Kerguelen hotspot magma output since 130 Ma. J. Petrol. 2002, 43, 1121-1139. [CrossRef]

29. Kerr, A.C.; White, R.V.; Saunders, A.D. LIP Reading: Recognizing Oceanic Plateaux in the Geological Record. J. Petrol. 2000, 41, 1041-1056. [CrossRef]

30. Fitton, J.G.; Godard, M. Origin and evolution of magmas on the Ontong Java Plateau. Geol. Soc. Lond. Spec. Publ. 2004, 229, 151-178. [CrossRef]

31. Hoernle, K.; Hauff, F.; van den Bogaard, P.; Werner, R.; Mortimer, N.; Geldmacher, J.; Garbe-Schönberg, D.; Davy, B. Age and geochemistry of volcanic rocks from the Hikurangi and Manihiki oceanic Plateaus. Geochim. Cosmochim. Acta 2010, 74, 7196-7219. [CrossRef]

32. Bagheri, S.; Stampfli, G.M. The Anarak, Jandaq and Posht-e-Badam metamorphic complexes in central Iran: New geological data, relationships and tectonic implications. Tectonophysics 2008, 451, 123-155. [CrossRef]

33. Zanchetta, S.; Berra, F.; Zanchi, A.; Bergomi, M.; Caridroit, M.; Nicora, A.; Heidarzadeh, G. The record of the Late Palaeozoic active margin of the Palaeotethys in NE Iran: Constraints on the Cimmerian orogeny. Gondwana Res. 2013, 24, 1237-1266. [CrossRef]

34. Mohammadi, A.; Burg, J.-P.; Winkler, W.; Ruh, J.; von Quadt, A. Detrital zircon and provenance analysis of Late Cretaceous-Miocene onshore Iranian Makran strata: Implications for the tectonic setting. Geol. Soc. Am. Bull. 2016, 128, 1481-1499. [CrossRef]

35. Pirnia, T.; Saccani, E.; Torabi, G.; Chiari, M.; Gorican, S.; Barbero, E. Cretaceous tectonic evolution of the Neo-Tethys in Central Iran: Evidence from petrology and age of the Nain-Ashin ophiolitic basalts. Geosci. Front. 2020, 11, 57-81. [CrossRef]

36. Eftekhar-Nezhad, J.; Arshadi, S.; Mahdavi, M.A.; Morgan, K.H.; McCall, G.J.H.; Huber, H. Fannuj Quadrangle Map 1:250,000 Scale; Ministry of Mines and Metal, Geological Survey of Iran: Tehran, Iran, 1979.

37. Samimi Namin, M. Geological Map of Taherui 1:250,000 Scale; Ministry of Mines and Metal, Geological Survey of Iran: Tehran, Iran, 1982.

38. Samimi Namin, M. Geological Map of Minab 1:250,000 Scale; Ministry of Mines and Metal, Geological Survey of Iran: Tehran, Iran, 1983. 
39. Riaz, M.S.; Bin, S.; Naeem, S.; Kai, W.; Xie, Z.; Gilani, S.M.M.; Ashraf, U. Over 100 years of faults interaction, stress accumulation, and creeping implications, on Chaman Fault System, Pakistan. Int. J. Earth Sci. 2019, 108, 1351-1359. [CrossRef]

40. Dercourt, J.; Zonenshian, L.P.; Ricou, L.E.; Kazmin, V.G.; LePichon, X.; Knipper, A.L.; Grandjacquet, C.; Sbortshikov, M.; Geyssant, J.; Lepvrier, C.; et al. Geological evolution of the Tethys Belt from the Atlantic to the Pamir since the Lias. Tectonophysics 1986, 123, 241-315. [CrossRef]

41. Ricou, L.E. Tethys reconstructed: Plates continental fragments and their boundaris since 260Ma from Central America to South-eastern Asia. Geodin. Acta 1994, 7, 169-218. [CrossRef]

42. Glennie, K.W.; Hughes Clarke, M.W.; Boeuf, M.G.A.; Pilaar, W.F.H.; Reinhardt, B.M. Inter-relationship of Makran-Oman Mountains belts of convergence. Geol. Soc. Lond. Spec. Publ. 1990, 49, 773-786. [CrossRef]

43. Barrier, E.; Vrielynck, B.; Brouillet, J.F.; Brunet, M.F. Paleotectonic Reconstruction of the Central Tethyan Realm. Tectonono-Sedimentary-Palinspastic Maps from Late Permian to Pliocene; Atlas of 20 Maps (scale: 1:15,000,000); Ccgm/Cgmw: Paris, France, 2018.

44. Penney, C.; Tavakoli, F.; Saadat, A.; Nankali, H.R.; Sedighi, M.; Khorrami, F.; Sobouti, F.; Rafi, Z.; Copley, A.; Jackson, J.; et al. Megathrust and accretionary wedge properties and behaviour in the Makran subduction zone. Geophys. J. Int. 2017, 209, 1800-1830. [CrossRef]

45. Motaghi, K.; Shabanian, E.; Nozad-Khalil, T. Deep structure of the western coast of the Makran subduction zone, SE Iran. Tectonophysics 2020, 776, 228314. [CrossRef]

46. Dolati, A. Stratigraphy, Structure Geology and Low-Temperature Thermochronology across the Makran Accretionary Wedge in Iran. Ph.D. Thesis, ETH Zurich, Zürich, Switzerland, 2010; p. 165.

47. McCall, G.J.H. Explanatory text of the Minab Quadrangle Map 1:250,000 scale, No. J13; Geological Survey of Iran: Tehran, Iran, 1985; p. 530.

48. McCall, G.J.H. The geotectonic history of the Makran and adjacent areas of southern Iran. J. Asian Earth Sci. 1997, 15, 517-531. [CrossRef]

49. Platt, J.P.; Leggett, J.K.; Young, J.; Raza, H.; Alam, S. Large-scale sediment underplating in the Makran accretionary prism, southwest Pakistan. Geology 1985, 13, 507. [CrossRef]

50. Burg, J.-P.; Bernoulli, D.; Smit, J.; Dolati, A.; Bahroudi, A. A giant catastrophic mud-and-debris flow in the Miocene Makran. Terra Nova 2008, 20, 188-193. [CrossRef]

51. Delavari, M.; Dolati, A.; Marroni, M.; Pandolfi, L.; Saccani, E. Association of MORB and SSZ ophiolites along the shear zone between Coloured Mélange and Bajgan Complexes (North Maran, Iran): Evidence from the Sorkhband area. Ofioliti 2016, 41, 21-34. [CrossRef]

52. Hunziker, D. Magmatic and Metamorphic History of the North Makran Ophiolites and Blueschists (SE Iran): Influence of $\mathrm{Fe}^{3+} / \mathrm{Fe}^{2+}$ Ratios in Blueschist Facies Minerals on Geothermobarometric Calculations. Ph.D. Thesis, ETH Zurich, Zurich, Switzerland, 2014; p. 364.

53. Desmons, J.; Beccaluva, L. Mid-Ocean ridge and island-arc affinities in ophiolites from Iran: Palaeographic implications. Chem. Geol. 1983, 39, 39-63. [CrossRef]

54. McCall, G.J.H. Mélanges of the Makran, southeastern Iran. In Ophiolitic and Related Mélanges; McCall, G.J.H., Ed.; Benchmark Papers in Geology 66; Hutchinson Ross Publishing Company: Stroudsburg, PA, USA, 1983; pp. 292-299.

55. Dorani, M.; Arvin, M.; Oberhänsli, R.; Dargahi, S.P.-T. evolution of metapelites from the Bajgan complex in the Makran accretionary prism, south eastern Iran. Geochemistry 2017, 77, 459-475. [CrossRef]

56. Hassanzadeh, J.; Wernicke, B.P. The Neotethyan Sanandaj-Sirjan zone of Iran as an archetype for passive margin-arc transitions. Tectonics 2016, 35, 586-621. [CrossRef]

57. Delaloye, M.; Desmons, J. Ophiolites and mélange terranes in Iran: A geochronological study and its paleotectonic implications. Tectonophysics 1980, 68, 83-111. [CrossRef]

58. Omrani, H.; Moazzen, M.; Oberhänsli, R.; Moslempour, M.E. Iranshahr blueschist: Subduction of the inner Makran oceanic crust. J. Metamorph. Geol. 2017, 35, 373-392. [CrossRef]

59. Esmaeili, R.; Xiao, W.; Griffin, W.L.; Moghadam, H.S.; Zhang, Z.; Ebrahimi, M.; Zhang, J.; Wan, B.; Ao, S.; Bhandari, S. Reconstructing the Source and Growth of the Makran Accretionary Complex: Constraints from Detrital Zircon U-Pb Geochronology. Tectonics 2020, 39. [CrossRef]

60. Lachance, G.R.; Trail, R.J. Practical solution to the matrix problem in X-ray analysis. Can. Spectrosc. 1966, $11,43-48$. 
61. Govindaraju, K. 1994 compilation of working values and sample description for 383 geostandards. Geostand. Newsl. 1994, 18, 1-58. [CrossRef]

62. Droop, G.T.R. A general equation for estimating $\mathrm{Fe}^{3+}$ concentrations in ferromagnesian silicates and oxides from microprobe analyses, using stochiometric criteria. Mineral. Mag. 1987, 51, 431-435. [CrossRef]

63. Hiess, J.; Condon, D.J.; McLean, N.; Noble, S.R. ${ }^{238} \mathrm{U} /{ }^{235} \mathrm{U}$ systematics in terrestrial Uranium-bearing minerals. Science 2012, 335, 1610-1614. [CrossRef]

64. Jackson, S.E.; Pearson, N.J.; Griffin, W.L.; Belousova, E. The application of laser ablation inductively coupled plasma mass spectrometry to in situ U-Pb zircon geochronology. Chem. Geol. 2004, 211, 47-69. [CrossRef]

65. Wiedenbeck, M.; Allé, P.; Corfu, F.; Griffin, W.L.; Meier, M.; Oberli, F.; Von Quadt, A.; Roddick, J.C.; Spiegel, W. Three natural zircon standards for $\mathrm{U}-\mathrm{Th}-\mathrm{Pb}, \mathrm{Lu}-\mathrm{Hf}$, trace elements and REE analyses. Geostand. Newsl. 1995, 19, 1-23. [CrossRef]

66. Sláma, J.; Kosler, J.; Condon, D.J.; Crowley, J.L.; Gerdes, A.; Hanchar, J.M.; Horstwood, M.S.A.; Morris, G.A.; Nasdala, L.; Norberg, N.; et al. Plesovice zircon-a new natural reference material for $\mathrm{U}-\mathrm{Pb}$ and $\mathrm{Hf}$ isotopic microanalysis. Chem. Geol. 2008, 249, 1-35. [CrossRef]

67. Van Achterbergh, E.; Ryan, C.G.; Jackson, S.E.; Griffin, W. Data reduction software for LAICPMS. In Laser ablation ICPMS in the Earth Sciences: Principles and Applications; Sylvester, P., Ed.; Short Course Series; Mineralogical Association of Canada: Québec, QC, Canada, 2001; Volume 29, pp. 239-243.

68. Vermeesch, P. IsoplotR: A free and open toolbox for geochronology. Geosci. Front. 2018, 9, 1479-1493. [CrossRef]

69. Stakes, D.S.; Taylor, H.P. Oxygen isotope and chemical studies on the origin of large plagiogranite bodies in northern Oman, and their relationship to the overlying massive sulphide deposits. Geol. Soc. Lond. Spec. Publ. 2003, 218, 315-351. [CrossRef]

70. Rollinson, H. New models for the genesis of plagiogranites in the Oman ophiolite. Lithos 2009, 112, 603-614. [CrossRef]

71. Beccaluva, L.; Di Girolamo, P.; Macciotta, G.; Morra, V. Magma affinities and fractionation trends in ophiolites. Ofioliti 1983, 8, 307-324.

72. Pearce, J.A.; Norry, M.J. Petrogenetic implications of $\mathrm{Ti}, \mathrm{Zr}, \mathrm{Y}$, and $\mathrm{Nb}$ variations in volcanic rocks. Contrib. Mineral. Petrol. 1979, 69, 33-47. [CrossRef]

73. Sun, S.S.; McDonough, W.F. Chemical and isotopic systematics of oceanic basalts: Implications for mantle composition and processes. In Magmatism in the Ocean Basins; Saunders, A.D., Norry, M.J., Eds.; Geological Society of London Special Publication: London, UK, 1989; Volume 42, pp. 313-345.

74. Winchester, J.A.; Floyd, P.A. Geochemical discrimination of different magma series and their differentiation products using immobile elements. Chem. Geol. 1977, 20, 325-343. [CrossRef]

75. Pearce, J.A. A user's guide to basalt discrimination diagrams. In Trace Element Geochemistry of Volcanic Rocks: Applications for Massive Sulphide Exploration. Short Course Notes; Bailes, A.H., Christiansen, E.H., Galley, A.G., Jenner, G.A., Keith, J.D., Kerrich, R., Lentz, D.R., Lesher, C.M., Lucas, S.B., Ludden, J.N., Eds.; Geological Association of Canada: Saint John, NL, Canada, 1996; Volume 12, pp. 79-113.

76. Parlak, O.; Bağcı, U.; Rızaoğlu, T.; Ionescu, C.; Önal, G.; Höck, V.; Kozlu, H. Petrology of ultramafic to mafic cumulate rocks from the Göksun (Kahramanmaraş) ophiolite, southeast Turkey. Geosci. Front. 2020, 11, 109-128. [CrossRef]

77. Burns, L.E. The Border Ranges ultramafic and mafic complex, south-central Alaska: Cumulate fractionates of island-arc volcanics. Can. J. Earth Sci. 1985, 22, 1020-1038. [CrossRef]

78. Hébert, R.; Laurent, R. Mineral chemistry of the plutonic section of the Troodos ophiolite: New constraints for genesis of arc-related ophiolites. In Troodos Ophiolite Symposium; Malpas, J., Moores, E., Panayiotou, A., Xenophontos, C., Eds.; Ministry agric. natural resources, geol. survey dep, Nicosia: Nicosia, Cyprus, 1990; pp. 149-163.

79. Sisson, T.W.; Grove, T.L. Experimental investigations of the role of $\mathrm{H}_{2} \mathrm{O}$ in calc-alkaline differentiation and subduction zone magmatism. Contrib. Mineral. Petrol. 1993, 113, 143-166. [CrossRef]

80. Ross, K.; Elthon, D. Cumulates from strongly depleted mid-ocean-ridge basalt. Nature 1993, 365, 826-829. [CrossRef]

81. Morimoto, N. Nomenclature of Pyroxenes. Mineral. Petrol. 1988, 39, 55-76. [CrossRef]

82. Beccaluva, L.; Macciotta, G.; Piccardo, G.B.; Zeda, O. Clinopyroxene composition of ophiolite basalts as petrogenetic indicator. Chem. Geol. 1989, 77, 165-182. [CrossRef] 
83. Allègre, C.J.; Minster, J.F. Quantitative models of trace element behaviour in magmatic processes. Earth Planet. Sci. Lett. 1978, 38, 1-25. [CrossRef]

84. Rollinson, H. Using Geochemical Data: Evaluation, Presentation, Interpretation; Longman Scientific: Harlow, UK, 1993; p. 352.

85. Saccani, E.; Azimzadeh, Z.; Dilek, Y.; Jahangiri, A. Geochronology and petrology of the Early Carboniferous Misho Mafic Complex (NW Iran), and implications for the melt evolution of Paleo-Tethyan rifting in Western Cimmeria. Lithos 2013, 162-163, 264-278. [CrossRef]

86. Saccani, E.; Photiades, A.; Padoa, E. Geochemistry, petrogenesis and tectono-magmatic significance of volcanic and subvolcanic rocks from the Koziakas Mélange (Western Thessaly, Greece). Ofioliti 2003, 28, 43-57.

87. Bortolotti, V.; Chiari, M.; Kodra, A.; Marcucci, M.; Mustafa, F.; Principi, G.; Saccani, E. New evidence for Triassic MORB magmatism in the northern Mirdita Zone ophiolites (Albania). Ofioliti 2004, 29, 243-246.

88. Chiari, M.; Djeric, N.; Garfagnoli, F.; Hrvatovic, H.; Krstiç, M.; Levi, N.; Malasoma, A.; Marroni, M.; Menna, F.; Nirta, G.; et al. The geology of the Zlatibor-Maljen area (Western Serbia): A geotraverse across the Dinaric-Hellenic collisional belt. Ofioliti 2011, 36, 139-166.

89. Le Roex, A.P.; Dick, H.J.B.; Erlank, A.J.; Reid, A.M.; Frey, F.A.; Hart, S.R. Geochemistry, Mineralogy and Petrogenesis of Lavas Erupted along the Southwest Indian Ridge Between the Bouvet Triple Junction and 11 Degrees East. J. Petrol. 1983, 24, 267-318. [CrossRef]

90. Saccani, E.; Allahyari, K.; Rahimzadeh, B. Petrology and geochemistry of mafic magmatic rocks from the Sarve-Abad ophiolites (Kurdistan region, Iran): Evidence for interaction between MORB-type asthenosphere and OIB-type components in the southern Neo-Tethys Ocean. Tectonophysics 2014, 621, 132-147. [CrossRef]

91. Hanan, B.B.; Blichert-Toft, J.; Kingsley, R.; Schilling, J.-G. Depleted Iceland mantle plume geochemical signature: Artifact of multicomponent mixing? Geochem. Geophys. Geosyst. 2000, 1. [CrossRef]

92. Chauvet, F.; Lapierre, H.; Maury, R.C.; Bosch, D.; Basile, C.; Cotten, J.; Brunet, P.; Campillo, S. Triassic alkaline magmatism of the Hawasina Nappes: Post-breakup melting of the Oman lithospheric mantle modified by the Permian Neotethyan Plume. Lithos 2011, 122, 122-136. [CrossRef]

93. Kinzler, R.J. Melting of mantle peridotite at pressures approaching the spinel to garnet transition: Application to mid-ocean ridge basalt petrogenesis. J. Geophys. Res. 1997, 102, 853-874. [CrossRef]

94. Thirlwall, M.F.; Upton, B.G.J.; Jenkins, C. Interaction between Continental Lithosphere and the Iceland Plume-Sr-Nd-Pb Isotope Geochemistry of Tertiary Basalts, NE Greenland. J. Petrol. 1994, 35, 839-879. [CrossRef]

95. Saccani, E.; Allahyari, K.; Beccaluva, L.; Bianchini, G. Geochemistry and petrology of the Kermanshah ophiolites (Iran): Implication for the interaction between passive rifting, oceanic accretion, and OIB-type components in the Southern Neo-Tethys Ocean. Gondwana Res. 2013, 24, 392-411. [CrossRef]

96. Workman, R.K.; Hart, S.R. Major and trace element composition of the depleted MORB mantle (DMM). Earth Planet. Sci. Lett. 2005, 231, 53-72. [CrossRef]

97. Lustrino, M.; Melluso, L.; Morra, V. The transition from alkaline to tholeiitic magmas: A case study from the Orosei-Dorgali Pliocene volcanic district (NE Sardinia, Italy). Lithos 2002, 63, 83-113. [CrossRef]

98. Haase, K.M.; Devey, C.W. Geochemistry of lavas from the Ahu and Tupa volcanic fields, Easter Hotspot, southeast Pacific: Implications for intraplate magma genesis near a spreading axis. Earth Planet. Sci. Lett. 1996, 137, 129-143. [CrossRef]

99. Bortolotti, V.; Chiari, M.; Göncüoglu, M.C.; Principi, G.; Saccani, E.; Tekin, U.K.; Tassinari, R. The Jurassic-Early Cretaceous basalt-chert association in the ophiolites of the Ankara Mélange, east of Ankara, Turkey: Age and geochemistry. Geol. Mag. 2017, 155, 451-478. [CrossRef]

100. McKenzie, D.; O'Nions, R.K. Partial melt distributions from inversion of rare earth element concentrations. J. Petrol. 1991, 32, 1021-1091. [CrossRef]

101. Klemme, S.; Gunther, D.; Hametner, K.; Prowatke, S.; Zack, T. The partitioning of trace elements between ilmenite, ulvospinel, armalcolite and silicate melts with implications for the early differentiation of the moon. Chem. Geol. 2006, 234, 251-263. [CrossRef]

102. Salters, V.; Longhi, J. Trace element partitioning during the initial stages of melting beneath mid-ocean ridges. Earth Planet. Sci. Lett. 1999, 166, 15-30. [CrossRef]

103. Ewart, A.; Griffin, W.L. Application of Proton-Microprobe Data to Trace-Element Partitioning in Volcanic-Rocks. Chem. Geol. 1994, 117, 251-284. [CrossRef] 
104. Horn, I.; Foley, S.F.; Jackson, S.E.; Jenner, G.A. Experimentally determined partitioning of high field strength-and selected transition elements between spinel and basaltic melt. Chem. Geol. 1994, 117, 193-218. [CrossRef]

105. Green, T.; Blundy, J.; Adam, J.; Yaxley, G. SIMS determination of trace element partition coefficients between garnet, clinopyroxene and hydrous basaltic liquids at 2-7.5 Gpa and 1080-1200 C. Lithos 2000, 53, 165-185. [CrossRef]

106. Dunn, T.; Sen, C. Mineral/Matrix Partition-Coefficients for Ortho-Pyroxene, Plagioclase, and Olivine in Basaltic to Andesitic Systems-a Combined Analytical and Experimental-Study. Geochim. Cosmochim. Acta 1994, 58, 717-733. [CrossRef]

107. Barbero, E.; Pandolfi, L.; Delavari, M.; Dolati, A.; Saccani, E.; Catanzariti, R.; Luciani, V.; Chiari, M.; Marroni, M. The western Durkan Complex (Makran Accretionary Prism, SE Iran): A Late Cretaceous tectonically disrupted seamounts chain and its role in controlling deformation style. Geosci. Front. 2020, in press.

108. Rolland, Y.; Hässig, M.; Bosch, D.; Bruguier, O.; Melis, R.; Galoyan, G.; Topuz, G.; Sahakyan, L.; Avagyan, A.; Sosson, M. The East Anatolia-Lesser Caucasus ophiolite: An exceptional case of large-scale obduction, synthesis of data and numerical modelling. Geosci. Front. 2020, 11, 83-108. [CrossRef]

109. Yang, G.; Dilek, Y. OIB- and P-type ophiolites along the Yarlung-Zangbo Suture Zone (YZSZ), Southern Tibet: Poly- Phase melt history and mantle sources of the Neotethyan oceanic lithosphere. Episodes 2015, 38, 250-265. [CrossRef]

110. Warren, J.M. Global variations in abyssal peridotite compositions. Lithos 2016, 248-251, 193-219. [CrossRef]

111. Saccani, E.; Dilek, Y.; Marroni, M.; Pandolfi, L. Continental margin ophiolites of Neotethys: Remnants of Ancient Ocean-Continent Transition Zone (OCTZ) lithosphere and their geochemistry, mantle sources and melt evolution patterns. Episodes 2015, 38, 230-249. [CrossRef]

Publisher's Note: MDPI stays neutral with regard to jurisdictional claims in published maps and institutional affiliations.

(C) 2020 by the authors. Licensee MDPI, Basel, Switzerland. This article is an open access article distributed under the terms and conditions of the Creative Commons Attribution (CC BY) license (http://creativecommons.org/licenses/by/4.0/). 